OPEN ACCESS

Edited by: Sebastian Fraune, Christian-Albrechts Universität Kiel, Germany

Reviewed by: Kimberly B. Ritchie, Mote Marine Laboratory, USA Erik Cordes,

Temple University, USA

*Correspondence: Christina A. Kellogg ckellogg@usgs.gov

Specialty section: This article was submitted to Microbial Symbioses, a section of the journal

Frontiers in Microbiology

Received: 11 December 2015 Accepted: 21 March 2016

Published: 05 April 2016

Citation:

Lawler SN, Kellogg CA, France SC, Clostio RW, Brooke SD and Ross SW (2016) Coral-Associated Bacterial Diversity Is Conserved across Two Deep-Sea Anthothela Species. Front. Microbiol. 7:458 doi: 10.3389/fmicb.2016.00458

\section{Coral-Associated Bacterial Diversity Is Conserved across Two Deep-Sea Anthothela Species}

\author{
Stephanie N. Lawler ${ }^{1}$, Christina A. Kellogg ${ }^{2 *}$, Scott C. France ${ }^{3}$, Rachel W. Clostio ${ }^{3}$, \\ Sandra D. Brooke ${ }^{4}$ and Steve W. Ross ${ }^{5}$ \\ ${ }^{1}$ College of Marine Science, University of South Florida, St. Petersburg, FL, USA, ${ }^{2}$ U.S. Geological Survey, St. Petersburg \\ Coastal and Marine Science Center, St. Petersburg, FL, USA, ${ }^{3}$ Department of Biology, University of Louisiana at Lafayette, \\ Lafayette, LA, USA, ${ }^{4}$ Coastal and Marine Laboratory, Florida State University, St. Teresa, FL, USA, ${ }^{5}$ Center for Marine \\ Science, University of North Carolina Wilmington, Wilmington, NC, USA
}

Cold-water corals, similar to tropical corals, contain diverse and complex microbial assemblages. These bacteria provide essential biological functions within coral holobionts, facilitating increased nutrient utilization and production of antimicrobial compounds. To date, few cold-water octocoral species have been analyzed to explore the diversity and abundance of their microbial associates. For this study, 23 samples of the family Anthothelidae were collected from Norfolk $(n=12)$ and Baltimore Canyons $(n=11)$ from the western Atlantic in August 2012 and May 2013. Genetic testing found that these samples comprised two Anthothela species (Anthothela grandiflora and Anthothela sp.) and Alcyonium grandiflorum. DNA was extracted and sequenced with primers targeting the V4-V5 variable region of the 16S rRNA gene using 454 pyrosequencing with GS FLX Titanium chemistry. Results demonstrated that the coral host was the primary driver of bacterial community composition. Al. grandiflorum, dominated by Alteromonadales and Pirellulales had much higher species richness, and a distinct bacterial community compared to Anthothela samples. Anthothela species (A. grandiflora and Anthothela sp.) had very similar bacterial communities, dominated by Oceanospirillales and Spirochaetes. Additional analysis of core-conserved bacteria at $90 \%$ sample coverage revealed genus level conservation across Anthothela samples. This core included unclassified Oceanospirillales, Kiloniellales, Campylobacterales, and genus Spirochaeta. Members of this core were previously recognized for their functional capabilities in nitrogen cycling and suggest the possibility of a nearly complete nitrogen cycle within Anthothela species. Overall, many of the bacterial associates identified in this study have the potential to contribute to the acquisition and cycling of nutrients within the coral holobiont.

Keywords: cold-water corals, deep sea, bacteria, octocoral, gorgonian, submarine canyons, microbiome

\section{INTRODUCTION}

Cold-water coral ecosystems contribute to vital biodiversity hotspots within the deep sea. Thriving in temperatures that range from 4 to $12^{\circ} \mathrm{C}$, these corals are globally distributed, occurring at depths between 50 and $4,000 \mathrm{~m}$ and inhabiting locations with strong currents and elevated topography (e.g., continental slopes and seamounts; Roberts and Hirshfield, 2004; White et al., 2005; Roberts et al., 2006). Similar to tropical reefs (Rohwer et al., 2002; Bourne and Munn, 2005), cold-water 
ecosystems provide a critical habitat for many organisms (Roberts et al., 2006) and are home to diverse and complex microbial assemblages (Penn et al., 2006; Neulinger et al., 2008, 2009; Hansson et al., 2009; Kellogg et al., 2009; Galkiewicz et al., 2011; Gray et al., 2011; Bourne and Webster, 2013). Research addressing the microbial communities associated with coldwater corals has been limited due to the expense of sampling, which can be directly linked to the difficulty of sample retrieval at depth. While many of these corals have been identified since the 1800s, the first microbial study of cold-water corals was not published until 2006. This study assessed microbiota associated with dead and living samples of the scleractinian coral Lophelia pertusa (Yakimov et al., 2006). That same year, Penn et al. (2006) evaluated bacterial communities associated with a black coral and several bamboo corals in the Gulf of Alaska. These two studies were the first to describe the microbial communities associated with stony and soft cold-water coral species as well as demonstrate differentiation between these deepsea coral-associated communities and those of their surrounding environments (sediment and water column). Since then, studies have characterized the microbial diversity of additional coldwater corals: L. pertusa (Kellogg, 2008; Neulinger et al., 2008; Hansson et al., 2009; Kellogg et al., 2009; Schottner et al., 2009; Galkiewicz et al., 2011), Madrepora oculata (Hansson et al., 2009), and octocorals Paragorgia arborea, Plumarella superba, and Cryogorgia koolsae (Gray et al., 2011).

Previous studies have examined bacterial function within the coral host microbiomes. While some bacteria appear to play commensal or pathogenic roles (Nissimov et al., 2009; Shnit-Orland and Kushmaro, 2009; Bourne and Webster, 2013), many are not static in function, fluctuating with transitioning environmental conditions [e.g., increased microbial pathogenicity upon exposure to elevated thermal stressors (Bruno et al., 2007; Ben-Haim et al., 2003a)]. Because corals are dependent (in part) on their microbe-host interactions, examining the "core conserved" communities may reveal insights into the overall health of the coral host (Shade and Handelsman, 2012; Krediet et al., 2013). Many variables influence the bacterial presence within the coral holobiont including: specificity to host (genus; Littman et al., 2009, or species; Rohwer et al., 2002), association within a host niche (e.g., tissue vs. mucus; Bourne and Munn, 2005; Koren and Rosenberg, 2006; Sweet et al., 2010; Ainsworth et al., 2015), or fluctuations in the surrounding environment (Pantos et al., 2003; Reshef et al., 2006; Ainsworth and Hoegh-Guldberg, 2009). While bacterial communities may vary based on these parameters, conserved bacteria necessary for coral host health, defined as the "core" community, are consistently present. Because little is known about the bacterial functions within the cold-water coral holobiont, it is necessary to identify the core microbiota of each coral species (defined as those common in more than one sample; Shade and Handelsman, 2012).

Because cold-water corals are azooxanthellate (they do not acquire nutrients through photosynthesis), they obtain their nutrients from floating particulates and planktonic organisms and the microbial functional potential expressed within the coral holobiont (White et al., 2005; Zhang et al., 2015). Understanding the metabolic pathways and biochemical processing of nutrients such as nitrogen, carbon, and sulfur are essential in coral health and development (Zhang et al., 2015). Based on phylogenetic inference and functional gene data, nitrogen-cycling microbes appear to be common members of tropical stony coral microbiomes (Wegley et al., 2007; Olson et al., 2009; Kimes et al., 2010; Lema et al., 2012, 2014; Olson and Lesser, 2013; Pratte, 2013; Yang et al., 2013, 2015) and have been suggested to be species-specific (Wafar et al., 1990; Lema et al., 2012). The process of nitrogen fixation has been detected in a number of tropical stony corals (Williams et al., 1987; Shashar et al., 1994; Grover et al., 2014; Rädecker et al., 2014), as has nitrification (Wafar et al., 1990). Most nitrogen cycling studies have been conducted on stony corals, but there are a couple of recent studies that provide evidence of similar activities (nitrogen fixation, nitrite reduction, and ammonia oxidation) in soft corals (Yang et al., 2013; Bednarz et al., 2015). A recent study has proposed that nitrogen cycling might play a significant role in supplementing nutrition within the cold-water coral, L. pertusa (Middelburg et al., 2015). While it is evident that nitrogen availability is one of the driving factors in the proliferation and health of tropical coral hosts, little is known about its influence in the cold-water coral holobionts.

In an effort to further our understanding of cold-water octocorals and their microbial associates, this study evaluated three corals from the family Anthothelidae, initially targeting the species Anthothela grandiflora. Endemic to the Atlantic Ocean, A. grandiflora was first observed off the coast of Nova Scotia in the mid-1800s (Whiteaves, 1901), but to date no microbial analysis has been completed. For this study, samples from 23 individual colonies of gorgonian corals visually identified as Anthothela were collected from Baltimore and Norfolk canyons off the east coast of the United States in the Mid-Atlantic Bight. Overall, our objective was to provide the first characterization of the bacterial diversity associated with the cold-water octocoral genus Anthothela. Based on tropical coral research, we hypothesized that (1) bacterial communities would be conserved at the species level (Rohwer et al., 2002), (2) that different canyons might influence the bacterial community composition (Littman et al., 2009; Barott et al., 2011), and (3) that nitrogen-cycling microbes would be an important part of Anthothela spp. holobionts and constitute part of the core microbiome (Lema et al., 2012, 2014; Rädecker et al., 2015).

\section{MATERIALS AND METHODS}

\section{Sample Sites and Collections}

In total, 23 individual Anthothelidae colonies were sampled during two research cruises conducted in August 2012 and May 2013. Site locations in the Mid-Atlantic Bight included Baltimore Canyon, which was sampled using the Kraken II remotely-operated vehicle (ROV; University of Connecticut) in 2012 and Norfolk Canyon sampled using the Jason II ROV (Woods Hole Oceanographic Institution) in 2013 (Figure 1). Environmental parameters were recorded for each sample site including location (latitude and longitude), depth, temperature, and salinity (Table 1). Depths of sample collection ranged 
A

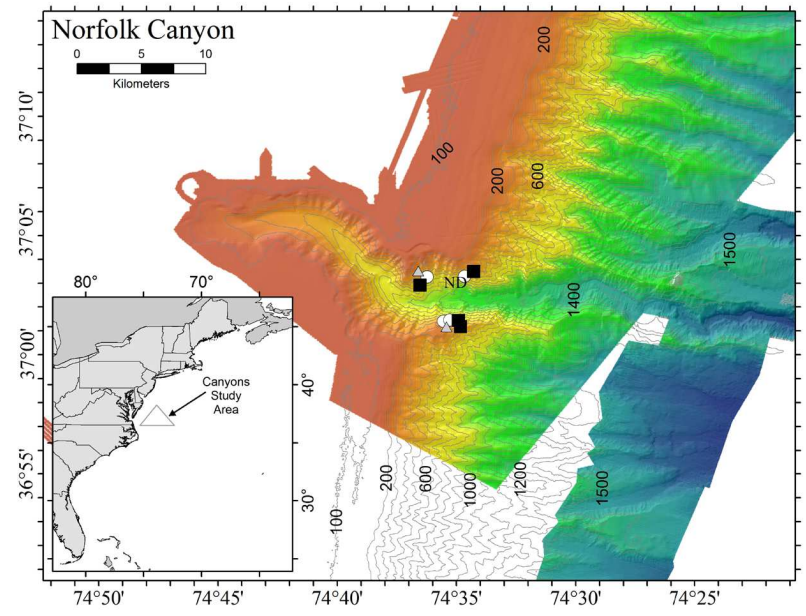

B

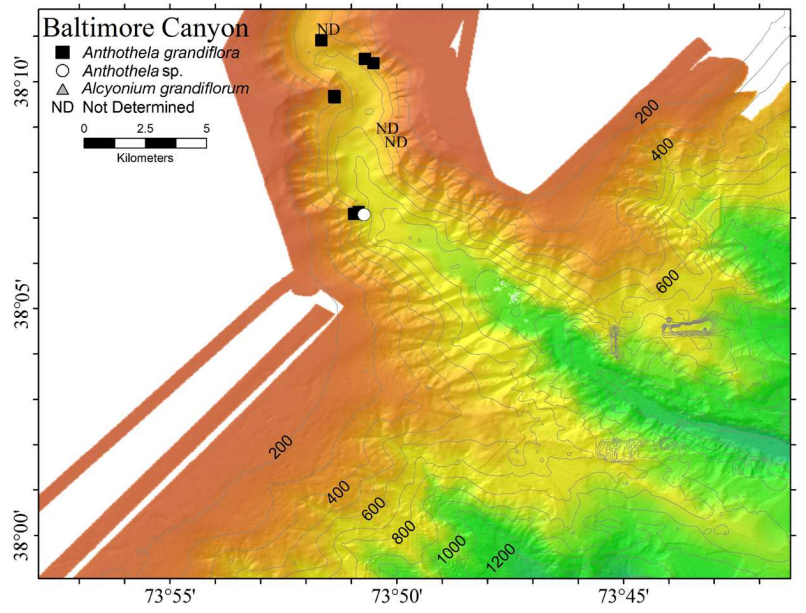

FIGURE 1 | Map of collection sites. Samples were collected from two submarine canyons, (A) Norfolk and (B) Baltimore, located off the Mid-Atlantic coast of the United States. Symbol shapes defined in the legend distinguish the coral samples based on genetic identification (e.g., Anthothela grandiflora, Anthothela sp., and Alcyonium grandiflorum).

from 401 to $704 \mathrm{~m}$. Bottom types varied from rocky seafloor to rock cliffs and ledges. Common benthic fauna present at sample sites associated with coral colonies included adult galatheid squat lobsters (Eumunida picta) and cutthroat eels (Synaphobranchidae). Several scleractinians and octocorals were present in the vicinity of Anthothelidae colonies, including Desmophylum, Paragorgia, and Primnoa species.

Because some species of Anthothelidae can grow over other organisms, including dead coral branches and sponges, great care was taken to select sections of polyps from the tips of

TABLE 1 | Sample collection and corresponding environmental data.

\begin{tabular}{|c|c|c|c|c|c|c|c|c|}
\hline Coral & Year & Canyon & ID \# & Latitude & Longitude & Depth (m) & Temp ( $\left.{ }^{\circ} \mathrm{C}\right)$ & Salinity (psu) \\
\hline Anthothela grandiflora & 2012 & Baltimore & NF.13Q6 & 38.161487 & -73.856465 & 434 & 7.1 & 35.1 \\
\hline Anthothela grandiflora & 2012 & Baltimore & NF.13Q7 & 38.161070 & -73.856163 & 432 & 7.5 & 35.1 \\
\hline Anthothela grandiflora & 2012 & Baltimore & NF.15Q6 & 38.173512 & -73.841965 & 416 & 7.2 & 35.1 \\
\hline Anthothela grandiflora & 2012 & Baltimore & NF.15Q7 & 38.175122 & -73.845125 & 457 & 6.8 & 35.1 \\
\hline Anthothela grandiflora & 2012 & Baltimore & NF.16Q7 & 38.181985 & -73.861092 & 436 & 6.3 & 35.0 \\
\hline Anthothela grandiflora & 2012 & Baltimore & NF.17Q6 & 38.118832 & -73.847417 & 575 & 5.7 & 35.0 \\
\hline Anthothela grandiflora & 2012 & Baltimore & NF.17Q7 & 38.118210 & -73.847688 & 575 & 5.7 & 35.0 \\
\hline Anthothela grandiflora & 2012 & Baltimore & NF.18Q7 & 38.117922 & -73.845465 & 679 & 5.1 & 35.0 \\
\hline Anthothela grandiflora & 2013 & Norfolk & RB.686Q4 & 37.054690 & -74.603935 & 581 & 5.9 & 35.0 \\
\hline Anthothela grandiflora & 2013 & Norfolk & RB.687Q5 & 37.054808 & -74.578777 & 606 & 5.7 & 35.0 \\
\hline Anthothela grandiflora & 2013 & Norfolk & RB.688Q1 & 37.024297 & -74.588163 & 559 & 5.8 & 34.9 \\
\hline Anthothela grandiflora & 2013 & Norfolk & RB.688Q5 & 37.024247 & -74.588199 & 560 & 5.8 & 34.9 \\
\hline Anthothela sp. & 2012 & Baltimore & NF.18Q6 & 38.1181583 & -73.849030 & 524 & 5.5 & 35.0 \\
\hline Anthothela sp. & 2013 & Norfolk & RB.686Q5 & 37.054699 & -74.603939 & 581 & 5.9 & 35.0 \\
\hline Anthothela sp. & 2013 & Norfolk & RB.687Q3 & 37.054881 & -74.577786 & 594 & 5.6 & 35.0 \\
\hline Anthothela sp. & 2013 & Norfolk & RB.688Q2 & 37.023429 & -74.592413 & 474 & 6.5 & 35.0 \\
\hline Anthothela sp. & 2013 & Norfolk & RB.688Q4 & 37.024201 & -74.588153 & 559 & 5.8 & 34.9 \\
\hline Alcyonium grandiflorum & 2013 & Norfolk & RB.686Q2 & 37.058587 & -74.605852 & 480 & 6.6 & 35.1 \\
\hline Alcyonium grandiflorum & 2013 & Norfolk & RB.688Q3 & 37.023538 & -74.592445 & 474 & 6.4 & 35.0 \\
\hline ND* & 2012 & Baltimore & NF.01Q7 & 38.149448 & -73.837895 & 451 & 6.4 & 35.1 \\
\hline ND* & 2012 & Baltimore & NF.02Q7 & 38.144950 & -73.834483 & 401 & 6.8 & 35.1 \\
\hline ND* & 2012 & Baltimore & NF.16Q6 & 38.181962 & -73.860835 & 435 & 5.7 & 35.0 \\
\hline ND* & 2013 & Norfolk & RB.687Q4 & 37.053907 & -74.580567 & 704 & 5.3 & 35.0 \\
\hline
\end{tabular}

Highlighted samples $(n=16)$ were used in final analysis. *Samples listed as ND did not have genetic analysis completed. 
branches rather than the main stalk (Lumsden et al., 2007). This technique was employed to avoid accidental contamination of the sampled coral microbiome with that of the supporting organism. Branches were removed using the ROV's manipulator claw and each sample placed in an individual polyvinyl chloride (PVC) quiver. The quivers were cleaned before deployment using ethanol to remove any interior biofilms, filled with freshwater and sealed with a rubber stopper. This prevented contamination of the containers by the water column prior to sampling, during which the rubber stopper is removed and in situ seawater would replace the freshwater due to density differences. On the ship, coral samples were transferred from the ROV collection quivers to sterile $50 \mathrm{~mL}$ tubes containing the preservative RNAlater (Life Technologies, Grand Island, NY, USA). Samples were incubated overnight at $4^{\circ} \mathrm{C}$ to allow the preservative to penetrate the coral tissues and then stored at $-20^{\circ} \mathrm{C}$ until processing.

\section{Coral Genetic Identification}

Of the 23 samples collected for microbiology, sufficient biomass remained in 19 samples for genetic analysis of the octocoral host (Table 1). Octocorals were identified to genus initially using a key based on morphological characters (Bayer, 1981) and subsequently using a genetic barcode commonly applied to the Octocorallia: the mitochondrial mismatch repair gene homolog, mtMutS in combination with $\operatorname{cox} 1$ (McFadden et al., 2011). Total genomic DNA was extracted from octocoral tissue (whole polyps and adjacent coenenchyme) using a CTAB buffer and a single chloroform-only extraction method (Berntson et al., 2001; France, 2007), and quantified using the NanoDrop Lite Spectrophotometer (Thermo Scientific; USA).

PCR amplifications were conducted using GoTaq polymerase (Promega) and included 5X GoTaq ${ }^{\circledR}$ Green buffer, $2 \mathrm{mM} \mathrm{MgCl}$, $0.4 \mu \mathrm{M}$ dNTPs mix, $0.24 \mu \mathrm{M}$ of each primer, $5 \mu \mathrm{g}$ of bovine serum albumin (BSA, Sigma) and $1 \mathrm{U}$ of GoTaq ${ }^{\circledR}$ polymerase, with the following cycle profiles: for $m t M u t S$ [amplicon 825 base pair (bp) length] $95^{\circ} \mathrm{C}$ for $2 \mathrm{~min}, 35$ cycles of $95^{\circ} \mathrm{C}$ for $20 \mathrm{~s}, 50^{\circ} \mathrm{C}$ for $30 \mathrm{~s}, 72^{\circ} \mathrm{C}$ for $50 \mathrm{~s}$ and a final step of $72^{\circ} \mathrm{C}$ for $5 \mathrm{~min}$; for cox 1 (amplicon $990 \mathrm{bp}$ length) $94^{\circ} \mathrm{C}$ for $3 \mathrm{~min}, 30$ cycles of $94^{\circ} \mathrm{C}$ for $20 \mathrm{~s}, 46^{\circ} \mathrm{C}$ for $30 \mathrm{~s}, 72^{\circ} \mathrm{C}$ for $60 \mathrm{~s}$ and a final extension step of $72^{\circ} \mathrm{C}$ for $2 \mathrm{~min}$.

All PCR amplified products were sent to Beckman Coulter Genomics (Beckman Coulter, Inc., Sykesville, MD, USA) for Sanger sequencing. Sequence traces were edited at the University of Louisiana, Lafayette using Sequencher version 4.6 (Gene Codes Corporation; USA) and then each sequence was queried against the Genbank nucleotide database using the BLASTn algorithm (NCBI, Altschul et al., 1990), and compared to unpublished data of colleagues working on similar taxa. Sequences were aligned to those from other octocoral taxa being worked on in the France lab or acquired from GenBank using Clustal W (Thompson et al., 1994) in the program BioEdit (Hall, 1998), and indels checked against the translated amino acid sequences to maintain reading frame. Aligned sequence datasets were then analyzed using the maximum likelihood method in RaxML 7.2.8 through the CIPRES web-portal (Stamatakis et al., 2008).

\section{Nucleic Acid Extraction}

Two polyps $(\sim 50 \mathrm{mg})$ were removed from each coral sample using flame-sterilized forceps and dissecting shears. DNA was extracted using the MOBIO PowerPlant DNA Isolation Kit (MO BIO Laboratories; Carlsbad, CA, USA). Per Sunagawa et al. (2010), modifications to this protocol included the addition of lysozyme and extended incubation periods at room temperature 24 and $65^{\circ} \mathrm{C}$. Samples were then homogenized using $400 \mathrm{mg}$ each of sterile 0.1 and $0.5 \mathrm{~mm}$ zirconia/silica beads (BioSpec Products; Bartlesville, OK, USA) in a Mini-BeadBeater1 (Biospec Products; Sunagawa et al., 2010). The bacterial and universal primers 63F (5'CAGGCCTAACACATGCAAGTC3'; IDT; Iowa City, IA, USA; Marchesi et al., 1998) and 1542R (5'AAGGAGGTGATCCAGCCGCA3'; IDT; Pantos et al., 2003) were used to screen the samples to confirm amplification of the target $16 \mathrm{~S}$ bacterial rRNA genes, rather than the possible amplification of coral $18 \mathrm{~S}$ ribosomal rRNA genes by polymerase chain reaction (Galkiewicz and Kellogg, 2008). DNA concentrations from the extraction were quantified for each sample using a Quant-iT ${ }^{\mathrm{TM}}$ PicoGreen dsDNA Assay Kit (Invitrogen: Eugene, OR, USA) as outlined in the manufacturer's protocol and sent for sequencing.

\section{S rRNA Gene Pyrosequencing}

Unamplified DNA extracted from the samples was sequenced by 454 pyrosequencing (Selah Genomics; Greenville, SC, USA) using GS FLX Titanium chemistry and V4-V5 targeting primers following Roche 454's standard protocol for amplicons (Claesson et al., 2010): forward primer (5' AYTGGGYDTAAAGNG; IDT) and reverse primer (5' CGTATCGCCTCCCTCGCGCCATCAG; IDT). Sequence data from all samples were deposited in the NCBI Sequence Read Archive (SRA) under Bioproject number PRJNA296835.

\section{Bioinformatics and Statistical Analysis}

Analysis of the sequence data was conducted using the bioinformatics packages QIIME 1.5 .0 on the Data Intensive Academic Grid (DIAG), a National Science Foundation funded MRI-R2 project \#DBI-0959894, and QIIME 1.9.1 on the Amazon Elastic Compute Cloud (Amazon “EC2"; Caporaso et al., 2010). Our bioinformatics workflow and all resulting processed files are available online as a USGS data release (Kellogg and Lawler, 2015).

A total of 1,308,658 raw reads were generated from the 23 individual coral samples. Quality checks were performed using the split_libraries.py with the following parameters: sequence length (minimum sequence length of $200 \mathrm{bp}$ and a maximum length of $700 \mathrm{bp}$ ), a minimum average quality score of 25, a maximum of one primer mismatch, and a maximum of a six homopolymer run (Kunin et al., 2010). SFF files were split into individual sample libraries based on the designated 10 bp identification barcode assigned to each sample during library preparation. The 889,914 sequences that passed the quality checks were then denoised using denoiser_preprocess.py, denoiser.py, and inflate_denoiser_results.py. This process was employed to reduce the number of erroneous operational 
taxonomic units (OTUs) and increase the accuracy of the sequence processing (Quince et al., 2011). Samples containing fewer than 10,000 sequences were removed prior to OTU selection to maximize the sequence data available. Furthermore, corals with no confirmed genetic identification were also removed at this stage, leaving a final total of 16 samples (Table 1, highlighted). Moving forward, OTUs were selected using an open-reference method (pick_open_reference_otus.py), with a 97\% similarity threshold (Rideout et al., 2014). This method clustered sequences from each sample against the Greengenes reference database release 13_8 (DeSantis et al., 2006). Sequences that were not matched during the reference comparison were reevaluated using the de novo reference method. Sequences were then aligned using usearch (Edgar, 2010), which included the removal of chimeras. Representative OTU sequences (defined as one representative from each OTU) were selected, assigned a taxonomic classification (uclust; Edgar, 2010), and used to create a phylogenetic tree (Price et al., 2010). Sequences were then filtered to remove absolute singletons (defined as an OTU present only once in the analysis). Sequences classified as chloroplasts and mitochondria were removed from the OTU table as were any sequences classified as Eukarya or Archaea. Samples were then rarified to the number of sequences present in the smallest sample $(10,333)$ before further diversity analysis was completed. Analysis of the core diversity associated with the coral species was completed using compute_core_diversity.py.

Alpha and beta diversity calculations as well as relative abundance summaries were conducted using alpha_diversity.py, beta_diversity.py, and summarize_taxa_through_plots.py. Alpha diversity metrics included Chao index (Chao, 1984), Shannon diversity index (Shannon, 1948), and Simpson diversity index (Simpson, 1949) (Table 2). These indices were employed to assess the richness and evenness of the associated microbiota within each individual sample. To assess beta diversity (similarities or differences across samples), three matrices were used based on phylogenetic and taxonomic relationships between sequences. Weighted and unweighted unit fraction (UniFrac; Lozupone and Knight, 2005) measurements were recorded to evaluate the importance of the presence/absence of specific taxa within the samples (unweighted Unifrac) compared to the abundance of these taxa (weighted Unifrac; Fukuyama et al., 2012). BrayCurtis was also assessed to evaluate differences between each sample based on the number of sequences per OTUs. To visualize beta diversity, principal coordinate analysis ( $\mathrm{PCoA}$ ) plots were prepared in R-Studio (R Development Core Team, 2014) using the previously described metrics. In addition, pairwise analysis of similarities (ANOSIM) was performed to further examine the statistical variation between sample groups (e.g., environmental parameters, location, or species diversity; Chapman and Underwood, 1999). A similarity percentage (SIMPER) was also used to determine the key contributing families responsible for the observed patterns. This statistical analysis was completed using PRIMER-E Ltd (Clarke and Warwick, 2001) and R-Studio. Figures for this study were produced in R-Studio (R Development Core Team, 2014) using the vegan (Oksanen et al., 2015) and gplots packages (Warnes et al., 2015).

\section{RESULTS}

The octocoral hosts were initially identified as A. grandiflora based on morphology (to genus) and distribution (to species). Comparisons to the GenBank nucleotide database and unpublished data suggested these represented three different species: A. grandiflora (the most commonly collected Anthothelidae in both canyons and 12 of the 23 samples analyzed

TABLE 2 | Alpha diversity analysis of coral samples.

\begin{tabular}{|c|c|c|c|c|c|c|c|c|c|}
\hline Corals & Canyons & $\begin{array}{l}\text { Sample } \\
\text { ID }\end{array}$ & No. Reads* & $\begin{array}{c}\text { Operational taxonomic } \\
\text { units (OTUs) }\end{array}$ & $\begin{array}{c}\text { ACE } \\
\text { richness }\end{array}$ & $\begin{array}{c}\text { Chao1 } \\
\text { richness }\end{array}$ & $\begin{array}{l}\text { Shannon } \\
\text { index }\end{array}$ & $\begin{array}{l}\text { Simpson } \\
\text { index }\end{array}$ & $\begin{array}{l}\text { Simpson } \\
\text { evenness }\end{array}$ \\
\hline Anthothela grandiflora & Baltimore & NF.13Q6 & 29,474 & 43 & 69.70 & 62.13 & 1.53 & 0.52 & 0.048 \\
\hline Anthothela grandiflora & Baltimore & NF.13Q7 & 26,064 & 49 & 77.63 & 119.00 & 2.16 & 0.72 & 0.074 \\
\hline Anthothela grandiflora & Baltimore & NF.15Q6 & 19,005 & 40 & 82.93 & 97.75 & 1.59 & 0.61 & 0.064 \\
\hline Anthothela grandiflora & Baltimore & NF.15Q7 & 24,553 & 45 & 67.94 & 69.00 & 1.88 & 0.65 & 0.064 \\
\hline Anthothela grandiflora & Baltimore & NF.16Q7 & 25,060 & 42 & 81.75 & 105.33 & 1.61 & 0.54 & 0.052 \\
\hline Anthothela grandiflora & Baltimore & NF.17Q6 & 26,819 & 49 & 111.32 & 109.00 & 1.29 & 0.41 & 0.034 \\
\hline Anthothela grandiflora & Baltimore & NF.17Q7 & $10,333^{*}$ & 56 & 101.88 & 83.27 & 2.48 & 0.77 & 0.079 \\
\hline Anthothela grandiflora & Baltimore & NF.18Q7 & 11,969 & 95 & 210.69 & 209.833 & 2.51 & 0.76 & 0.044 \\
\hline Anthothela grandiflora & Baltimore & RB.686Q4 & 24,843 & 30 & 54.59 & 56.00 & 1.60 & 0.63 & 0.089 \\
\hline Anthothela grandiflora & Norfolk & RB.687Q5 & 14,269 & 66 & 135.65 & 109.50 & 2.52 & 0.76 & 0.062 \\
\hline Anthothela grandiflora & Norfolk & RB.688Q1 & 14,289 & 80 & 127.49 & 113.21 & 1.61 & 0.43 & 0.022 \\
\hline Anthothela grandiflora & Norfolk & RB.688Q5 & 298,193 & 77 & 115.09 & 110.00 & 1.90 & 0.55 & 0.029 \\
\hline Anthothela sp. & Baltimore & NF.18Q6 & 13,039 & 49 & 80.138 & 87.00 & 2.68 & 0.81 & 0.105 \\
\hline Anthothela sp. & Norfolk & RB.686Q5 & 32,479 & 67 & 96.61 & 101.50 & 2.38 & 0.74 & 0.067 \\
\hline Anthothela sp. & Norfolk & RB.688Q4 & 254,947 & 215 & 569.08 & 446.92 & 3.09 & 0.83 & 0.028 \\
\hline Alcyonium grandiflorum & Norfolk & RB.688Q3 & 13,216 & 423 & 454.32 & 457.44 & 5.54 & 0.87 & 0.018 \\
\hline
\end{tabular}

*All samples were rarified to 10,333 sequences before diversity indices were calculated. 
in this study), Anthothela sp. ( $n=5)$, and "Alcyonium" grandiflorum (the genus name is shown here in quotes to denote an ongoing systematic revision which will see Alcyonium grandiflorum transferred to a new genus in the family Anthothelidae; pers. comm., K. Moore, Commonwealth Science and Industrial Research Organisation, Australia; $n=2$; Table 1). Mitochondrial DNA sequences revealed three haplotypes using both mtMutS (GenBank accession numbers: A. grandiflora, KU712085; Anthothela sp. KU712082; Al. grandiflorum, KU712083 and KU712084) and cox1 (GenBank accession numbers: A. grandiflora, KU712079; Anthothela sp. KU712080; Al. grandiflorum, KU712081). The Al. grandiflorum sequences are highly divergent from both Anthothela species (from A. grandiflora uncorrected $p$ distance $=5 \%$ at mtMutS and $p=2 \%$ at $\operatorname{cox} 1$ ), but Anthothela sp. shows low sequence divergence from $A$. grandiflora ( $p$ distance $<0.2 \%$ at $m t M u t S$ and at cox1). Such a low level of interspecific divergence within a genus is not unusual for mitochondrial genes of octocorals (Pante and France, 2010; McFadden et al., 2011; Pante et al., 2015). Four of the 23 samples were not analyzed for coral genetics and were removed from our analysis (NF.01Q7, NF.02Q7, NF.16Q6, and RB.687Q4) although their bacterial sequence data are included in the SRA data file for completeness. In addition, samples with fewer than 10,000 sequence reads (NF.02Q7, RB.686Q2, RB.687Q3, and RB.688Q2) were removed before primary analysis to increase rarefaction depth. As such, 16 samples were analyzed further, nine from Baltimore Canyon (one Anthothela sp. and eight A. grandiflora samples) and seven from Norfolk Canyon (one Al. grandiflorum, two as Anthothela sp., and four A. grandiflora; Table 1, Figure 1).

\section{Alpha and Beta Measurements among Bacterial Diversity}

Phylogenetic relationships samples (beta diversity) were compared using three primary diversity matrices (weighted UniFrac, unweighted UniFrac, and Bray-Curtis) and visualized using principal coordinates analysis (PCoA). Diversity of samples was first evaluated based on coral host. Here, samples within the genus Anthothela (A. grandiflora and Anthothela sp.) clustered separately from Al. grandiflorum, accounting for $\sim 57 \%$ of the statistical variation (Figure 2 ). Due to the small sample size $(n=1), A l$. grandiflorum could not be included in the analysis of similarities (ANOSIM) to assess the correlation between bacterial diversity and coral species. Samples associated with Anthothela sp. and A. grandiflora were compared, revealing no significant difference between the two species (ANOSIM: $R=0.03, p=0.27$ ). Sample site was also assessed, indicating no significant correlation between coral-associated bacterial diversity and the canyon of origin (ANOSIM: $R=-0.02, p=0.45$ ). The influence of depth of sample sites, water temperature, and salinity were also examined by PCoA, but were not correlated with bacterial diversity (results not shown). Similarity percentage analysis (SIMPER) was then used to examine representative bacterial taxa (family level) responsible for the differentiation between Anthothela samples

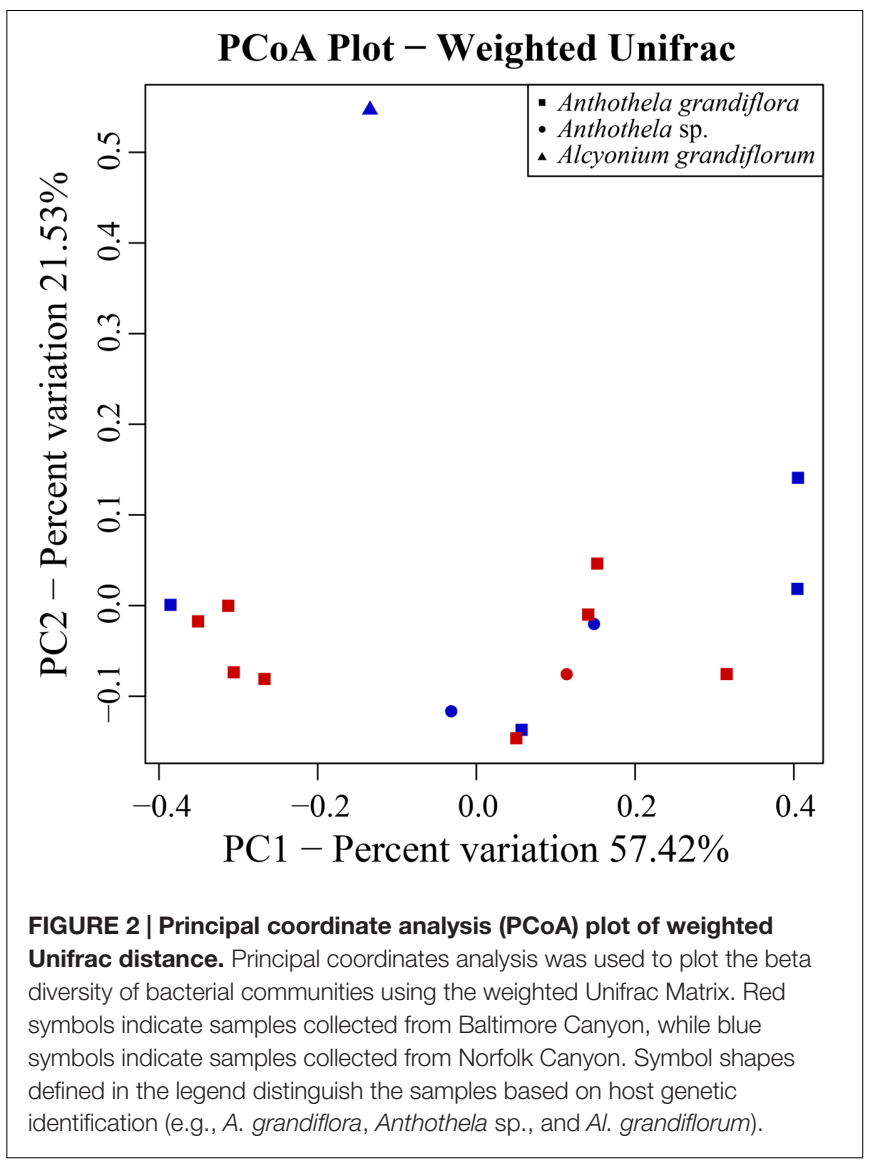

and Al. grandiflorum. Overall, Anthothela bacterial communities had an average similarity of $63 \%$. Considerable dissimilarity ( $\sim 72 \%$ ) was observed between Al. grandiflorum and Anthothela microbiomes. Contributing families included Shewanellaceae $(\sim 19 \%)$ and Pirellulaceae $(\sim 11 \%)$ which were only present in Al.grandiflorum. Unclassified Oceanospirillales (16\%), unclassified Spirochaetales (12\%), Spirochaetaceae (10\%), and Colwelliaceae (10\%) also defined the differences seen between Anthothela samples and Al. grandiflorum.

To measure the bacterial diversity present within each individual sample, a series of alpha diversity indices were used (Table 2). Shannon (Shannon, 1948), Simpson (Simpson, 1949), and Chao 1 (Chao, 1984) diversity indices account for evenness (defined as the abundance of species present) and richness (defined as the number of species or OTUs) as well as the total number of species observed. These measurements (Shannon $=5.54$, Simpson $=0.87$, and Chao $1=457.44)$ revealed greater species richness and evenness in the Al. grandiflorum sample compared to the rest of the Anthothela samples (Table 2). In general, Shannon measurements were fairly consistent across Anthothela samples (average Shannon $=2.27$ ) with increased diversity in two samples (RB.688Q4 = 2.68 and NF.18Q6 = 3.09). Similar trends were seen in Chao 1 and Simpson measurements. To visualize the diversity driving these patterns, bacterial communities were characterized at the phylum, order, and family levels for each coral host. 
A

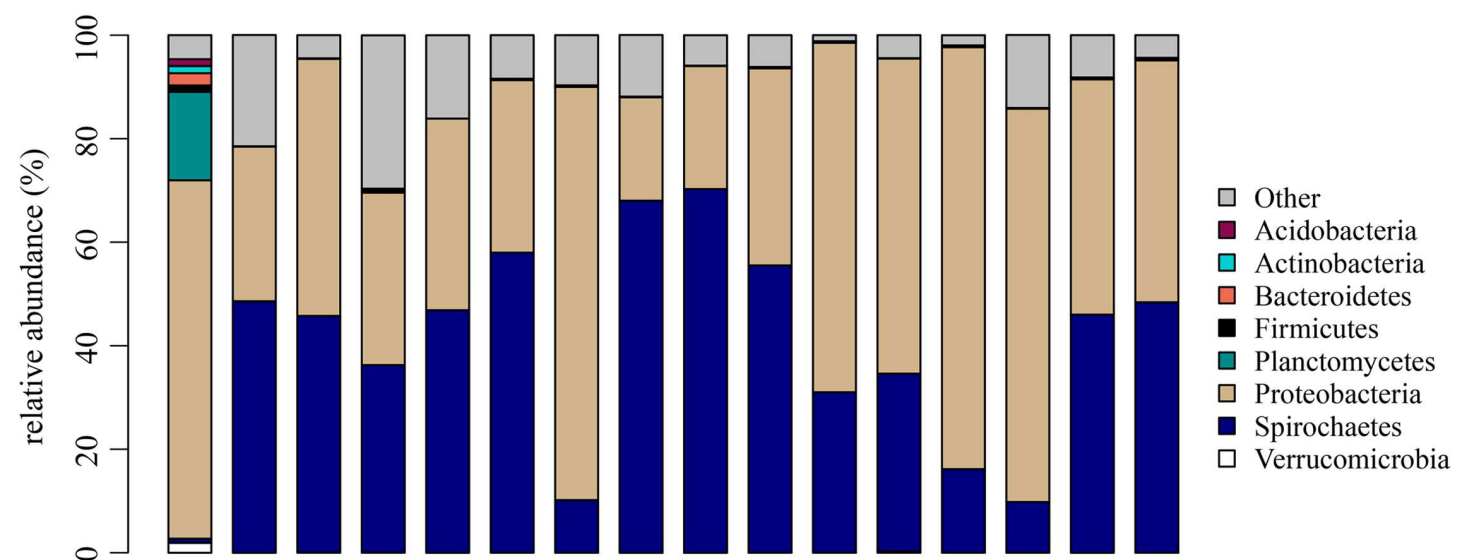
grandiflorum

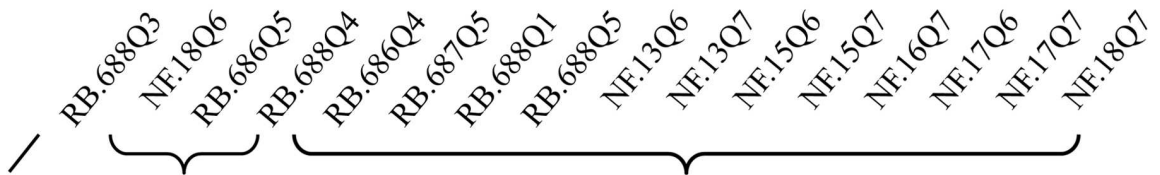

B

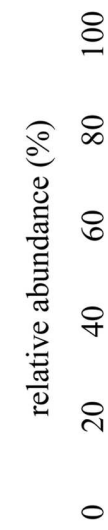

Anthothela sp.

Anthothela

grandiflora
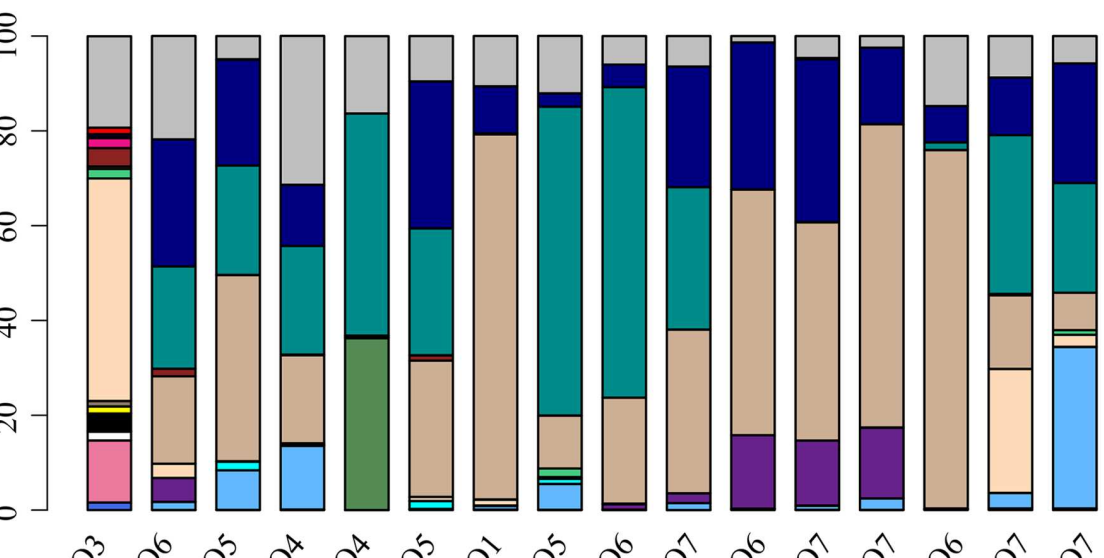

$\square$ Other

Verrucomicrobiales

- Spirochaetales

ㅁ Spirochaetes; Unclassified

․ Marinicellales

Vibrionales

$\square$ Oceanospirillales

Legionellales

Alteromonadales

Sva0853

Myxococcales

Desulfobacterales

Rickettsiales

․ Rhodobacterales

- Kiloniellales

$\square$ Caulobacterales

․ Planctomycetales

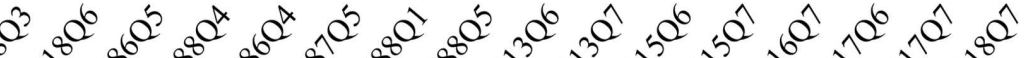

$\square$ Pirellulales

$\square$ Phycisphaerales

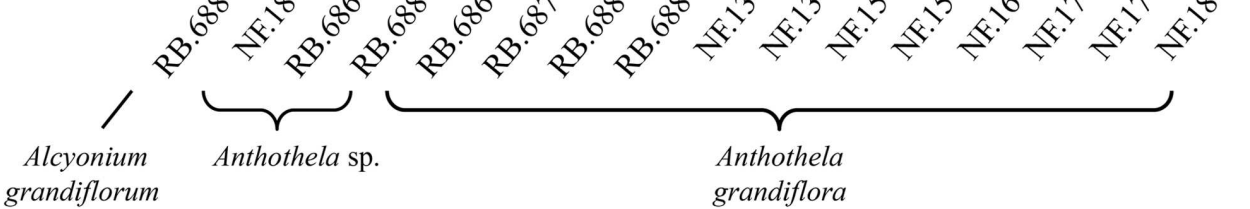

FIGURE 3 | Relative abundance of bacterial taxa in coral samples. (A) Phyla present at $\geq 1 \%$ relative abundance in at least one sample. All remaining taxa are summarized under "Other." (B) Orders present at $\geq 1 \%$ relative abundance in at least one sample. All remaining taxa are summarized under "Other." Samples collected from Baltimore Canyon begin with the letters "NF" and those from Norfolk Canyon with "RB."

\section{Bacterial Community Composition Associated with Al. grandiflorum}

Proteobacteria dominated the Al. grandiflorum sample (RB.688Q3), accounting for $\sim 69 \%$ of the relative abundance with Planctomycetes representing the second most abundant at $\sim 17 \%$ (Figure 3A). Additional minor contributors to the bacterial diversity included Bacteroidetes $(\sim 2 \%)$, Acidobacteria $(\sim 1 \%)$, Actinobacteria $(\sim 1 \%)$, Firmicutes $(\sim 1 \%)$, and Verrucomicrobia
( $\sim 1 \%)$. Phyla representative of less than $1 \%$ of the relative abundance of the sample were labeled as "Other" (representing $\sim 5 \%$ of the sample's relative abundance); some of these included Chlamydiae, Deferribacteres, Lentisphaerae, and Nitrospira.

The bulk of the bacterial diversity distinguishable at the order level was found within Al. grandiflorum (Figure 3B). Alteromonadales dominated bacterial diversity at $47 \%$ relative abundance, followed by Pirellulales, accounting for $13 \%$ of 
the relative abundances. Additional contributing bacterial populations included $\alpha$-proteobacteria (order Rhodobacterales), $\delta$-proteobacteria (orders Desulfobacterales and Myxococcales), and $\gamma$-proteobacteria (orders Legionellales and Vibrionales). Rhodobacterales and Vibrionales accounted for approximately $4 \%$ of the relative abundances with Desulfobacterales, Myxococcales, Marinicellales, Phycisphaerales, and Planctomycetales observed in the Al. grandiflorum sample, but at smaller relative abundance $(\sim 2 \%)$. Three of these five proteobacterial orders were only present in Al. grandiflorum: Rhodobacterales, Desulfobacterales, and Myxococcales.

Within the order Alteromonadales, Shewanellaceae $(\sim 35 \%)$, and Colwelliaceae $(\sim 11 \%)$ were both found at high relative abundance. Additionally, Pirellulaceae, under the order Pirellulales, contributed $\sim 13 \%$ of the relative abundance of this sample. Other contributing families present in less than $5 \%$ of the relative abundance of $\mathrm{Al}$. grandiflorum included: Verrucomicrobiaceae, Spirochaetaceae, Planctomycetaceae, Pseudoaltermonadaceae, Marinicellaceae, and Rhodobacteraceae. The bacterial genus Shewanella accounted for $\sim 35 \%$ relative abundance. Approximately $2 \%$ of the identifiable genera in Al. grandiflorum were named; these included Phaeobacter (family Rhodobacteraceae), Planctomyces (family Planctomycetaceae), and Pseudoalteromonas (family Pseudoalteromonadaceae). With the exception of Pseudoalteromonas, each was exclusively identified in $A l$. grandiflorum.

\section{Bacterial Community Composition of Anthothela}

In total, 15 coral samples were classified under the genus Anthothela, consisting of both A. grandiflora $(n=12)$ and an unknown Anthothela species $(n=3)$. At the phylum level, roughly half of the 15 samples were dominated by Proteobacteria ( $\sim 48 \%$ average relative abundance). The second most dominant bacterial group, Spirochaetes (Figure 3A), accounted for $\sim 42 \%$ average relative abundance of the Anthothela samples ( $\sim 43 \%$ in Anthothela sp. and $\sim 41 \%$ in A. grandiflora samples). Unlike the Al. grandiflorum sample, Proteobacteria and Spirochaetes were the only bacterial groups discernible at the phylum level. Phyla representative of less than $1 \%$ of the relative abundance in at least one sample were labeled as "Other" ( $\sim 10 \%$ of the total relative abundance). These included Chloroflexi, Lentisphaerae, and Nitrospira.

At the order level, all bacteria groups were classifiable with the exception of one, unclassified Spirochaetes (Figure 3B). Bacterial diversity associated with Anthothela genus samples (A. grandiflora and Anthothela sp.) varied slightly with key communities including: Oceanospirillales (34\%), unclassified Spirochaetes (24\%), and Spirochaetales (17\%). Other orders were observed at higher abundance in several of the Anthothela samples: Alteromonadales accounted for $26 \%$ of A. grandiflora sample NF.17Q7; Deltaproteobacteria Sva0853 were present in 6 of the 15 samples, ranging from 1 to $16 \%$ relative abundance. Kiloniellales were visibly represented in 10 samples, ranging from 1 to $34 \%$ relative abundance. Caulobacterales, with $\sim 36 \%$ relative abundance, were present in sample RB.686Q4. Bacterial groups observed in one or two of the Anthothela genus samples at lower relative abundance included: Rickettsiales present at 2\% in three Norfolk Canyon samples (RB.686Q5, RB.687Q5, and RB.688Q5); Legionellales accounting for $\sim 2 \%$ of samples RB.688Q5 and NF.18Q7; and Vibrionales present at $\sim 2 \%$ of samples RB.687Q5 and NF.18Q6. Three of the bacterial groups present in Anthothela samples were not observed in $\mathrm{Al}$. grandiflorum: Caulobacterales, Kiloniellales, and Rickettsiales.

Families and identifiable genera (present at greater than $1 \%$ relative abundance in at least one sample) were also assessed for Anthothela samples. Spirochaeta (order Spirochaetales, family Spirochaetaceae) were the most abundant bacteria (3-34\% relative abundance) observed in 13 of the 15 samples. The family identified as Endozoicomonaceae accounted for $~ 2 \%$ of two samples RB.687Q5 and RB.688Q1. Because we could not find this family defined in any taxonomic literature, sequences identified as Endozoicomonaceae were run through RDP Classifier (Wang et al., 2007) for further assessment. In Classifier, Endozoicomonaceae sequences were categorized as the family Hahellaceae. Lastly, Moritella sequences (order Alteromonadales, family Moritellaceae) were observed dominating A. grandiflora sample NF.17Q7, accounting for $\sim 26 \%$ relative abundance.

\section{Core Microbiome}

To evaluate the potential conserved-core diversity, samples were first assessed at the level of family Anthothelidae, i.e., across all 16 samples. One identifiable genus, Spirochaeta, was observed in every sample. Next, we evaluated the core diversity at the Anthothela genus level $(n=15)$. Assessment of Anthothela samples revealed no additional unique taxa, with Spirochaeta still the only shared taxon. From here, conserved bacteria were assessed at $90 \%$ sample coverage revealing four conserved communities: unclassified orders (Oceanospirillales, Kiloniellales, and Campylobacterales) and genus Spirochaeta (Figure 4). Individual species were examined at $100 \%$ sample coverage: A. grandiflora $(n=12)$ and Anthothela sp. $(n=3)$. A. grandiflora samples only shared the genus Spirochaeta, while Anthothela sp. included the genera Propionibacterium, Pseudoalteromonas as well as unclassified bacteria within Spirochaetes, Kiloniellales, Campylobacterales, Oceanospirillales, and Brachyspiraceae.

\section{DISCUSSION}

Relatively little is known about cold-water coral microbiomes in comparison to those of tropical corals. Prior to this study no microbial assessment had been completed on cold-water Anthothelidae corals. Because some tropical coral species have shown correlation between their bacterial composition and environmental parameters (e.g., geographic location, depth, ambient water-temperature, and surrounding organisms; Littman et al., 2009; Barott et al., 2011), similar relationships were anticipated within the host-microbe interactions of the cold-water corals collected during this study. However, bacterial composition of samples was not found to be significantly different 


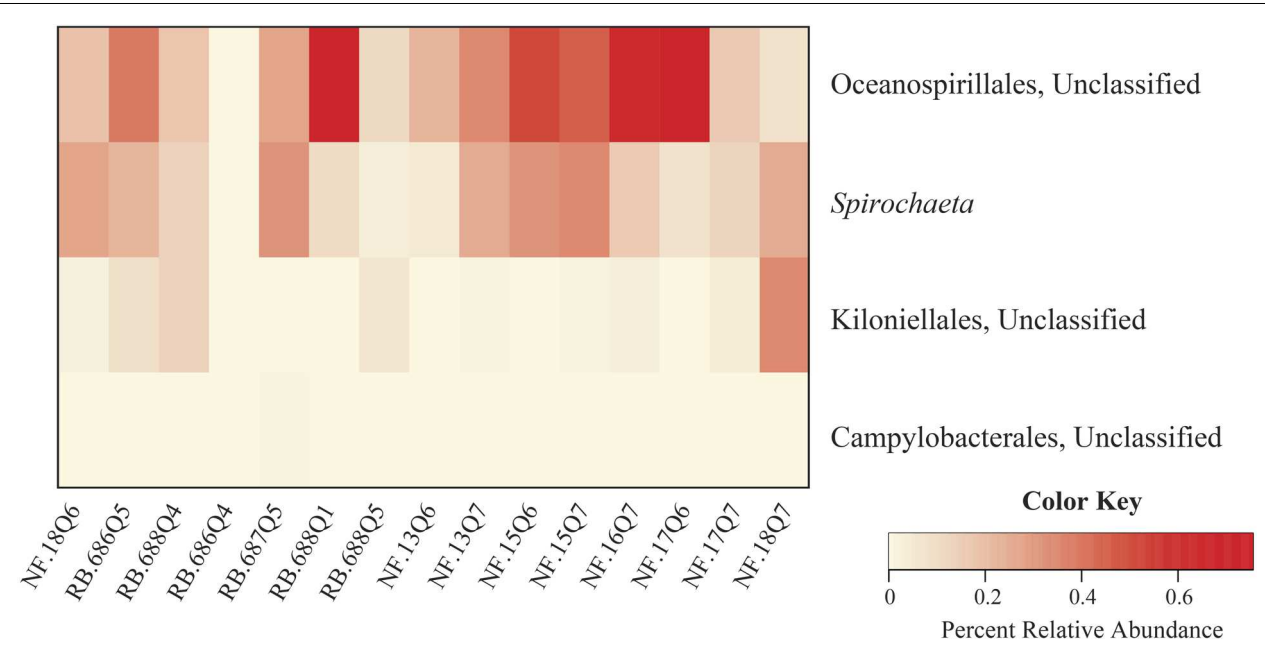

FIGURE 4 | Core microbiome of Anthothela samples. A heatmap was created to visualize the core community of the 15 samples within the Anthothela genus. Bacterial taxa represented in this figure were unique to the Anthothela spp. core microbiome present in $90 \%$ of the samples.

based on canyon of origin (Figure 2). Beta diversity matrices indicated relationships between the taxa present and their abundance drove the diversity. Alpha diversity measurements also indicated higher bacterial diversity in the Al. grandiflorum sample (Table 2). This as well as the ANOSIM results further supported the PCoA distribution showing the clustering of all Anthothela samples separate from Al. grandiflorum (RB.688Q3).

\section{Proteobacteria}

In most of the marine environment, Proteobacteria dominate the bacterial diversity (Amaral-Zettler et al., 2010). This is true for many tropical coral species (Frias-Lopez et al., 2002; Bourne and Munn, 2005; Thurber et al., 2009) as well as cold-water scleractinians and octocorals (Penn et al., 2006; Yakimov et al., 2006; Neulinger et al., 2008; Hansson et al., 2009; Galkiewicz et al., 2011; Van Bleijswijk et al., 2015). In this study a similar pattern was observed. Proteobacteria, primarily the orders Oceanospirillales, Kiloniellales, and Alteromonadales accounted for the majority of the diversity in samples. Other minor contributing Proteobacteria included Rhodobacterales, Desulfobacterales, Myxococcales, Legionellales, and Vibrionales.

\section{Proteobacteria in Al. grandiflorum}

Alteromonadales (specifically families Shewanellaceae and Colwelliaceae) were observed as the dominant order within Al. grandiflorum. Genera classified under these families are ubiquitous throughout marine environments, described in tropical (Bourne and Munn, 2005; Ritchie, 2006; Thompson et al., 2006; Shnit-Orland and Kushmaro, 2009; Shnit-Orland et al., 2010), temperate (La Rivière et al., 2015), and cold-water coral species (Kellogg, 2008; Kellogg et al., 2009; Galkiewicz et al., 2011; Gray et al., 2011). Their presence in cold-water environments was expected as many members of both Shewanellaceae and Colwelliaceae are psychrophilic (organisms capable of growing in cold, extreme environments; Bowman, 2014; Satomi, 2014).
Biochemical properties of Colwelliaceae members include energy production through the decomposition of organic matter and nitrate reduction (Bowman, 2014). Species classified under the genus Shewanella (family Shewanellaceae) are generally Gram-negative, facultative anaerobes, recognized for their roles in nitrate and iron reduction (Hau and Gralnick, 2007; Coursolle and Gralnick, 2012; Kim et al., 2012; Satomi, 2014). Prevalent throughout the marine environment, members of this family have been isolated from numerous deep-sea and cold-water environments including the Marianas Trench (Kato et al., 1998) and the Arctic Ocean (Kim et al., 2012). Shewanella isolated from the mucus of tropical coral genus Favia demonstrated both antibacterial properties and antibiotic resistance (Shnit-Orland and Kushmaro, 2009; Shnit-Orland et al., 2010). These beneficial or mutualistic relationships are thought to contribute to the overall health of the host organism, providing protection from pathogenic or opportunistic bacteria.

Members of the order Rhodobacterales, specifically the genus Rhodobacter are thought to be among the most abundant, diverse, and metabolically influential bacteria within the marine environment (accounting for $\sim 25 \%$ of the total bacteria present in coastal and polar regions; Wagner-Dobler and Biebl, 2006). Rhodobacterales are found ubiquitously amongst coral reef systems, typically observed in surface waters, reef invertebrates, and their associated biofilms (Galkiewicz and Kellogg, 2008; Sunagawa et al., 2009; Sharp et al., 2012; Roder et al., 2014; La Rivière et al., 2015). Functionally these bacteria are diverse, capable of contributing to the reduction of trace metals and the production of antibiotic compounds (Brinkhoff et al., 2004). Other notable members also contribute to the global carbon and sulfur cycles through the oxidization of carbon monoxide and production of dimethylsulfide (Wagner-Dobler and Biebl, 2006). To date a few Rhodobacterales (particularly members of the family Rhodobacteraceae) have been identified in cold-water coral species: Al. digitatum (Alsmark et al., 2012) and L. pertusa (Neulinger et al., 2008; Kellogg et al., 2009). 
Desulfobacterales (class $\alpha$-proteobacteria) are documented sulfate-reducing bacteria, functionally described as hydrogenotrophs (capable of using $\mathrm{H}_{2}$ as an energy source within the metabolic pathway; Kuever et al., 2005; Kimes et al., 2010). These members appear to be common within deep-sea ecosystems, including microbial mats (Burow et al., 2014), sediments (Simister et al., 2015), seeps (Jaekel et al., 2013), and one unidentified cold-water coral (Simister et al., 2015). In contrast, Myxococcales (class $\alpha$-proteobacteria) are commonly observed in terrestrial environments, with some present in marine ecosystems (though, notably less; Reichenbach and Dworkin, 1992). Several have been identified in coral species including Eunicella cavolini (Bayer et al., 2013a) and Mussismilia braziliensis (Garcia et al., 2013). Functionally these bacteria may contribute to the production of nutrients through sulfate reduction and the decomposition of organic matter (Reichenbach, 1999; Baker et al., 2015).

Legionellales and Vibrionales were each identified as a small percentage $(\sim 2 \%)$ of the bacterial community associated with $\mathrm{Al}$. grandiflorum. Legionellales, described as facultative or obligate intracellular parasites are recognized for infecting invertebrate and vertebrate species (Garrity et al., 2005). While commonly associated with marine environments, members of the Legionellales have rarely been identified in corals (tropical or cold-water; Meron et al., 2012; Ransome et al., 2014). Unlike Legionellales, Vibrio spp. (order Vibrionales) are common associates of shallow-water corals (Kushmaro et al., 2001; Rohwer et al., 2001; Ben-Haim et al., 2003a; Bourne and Munn, 2005; Lampert et al., 2006; Ritchie, 2006; Rosenberg et al., 2007) and have also been found in association with the cold-water coral species L. pertusa (Neulinger et al., 2008; Galkiewicz et al., 2011), E. verrucosa (Hall-Spencer et al., 2007), P. arborea, P. superba, and C. koolsae (Gray et al., 2011). Although, these bacteria are primarily acknowledged for their roles as opportunistic or pathogenic bacteria associated with coral disease and bleaching events (Toren et al., 1998; Ben-Haim et al., 2003a,b; HallSpencer et al., 2007; Sussman et al., 2008; Sweet and Bythell, 2012), they are also recognized as common members of healthy coral microbiomes (Bourne and Munn, 2005; Raina et al., 2009; Ainsworth et al., 2015).

\section{Proteobacteria in Anthothela Samples}

Oceanospirillales was identified as one of the dominant bacterial groups in Anthothela samples, present in eight samples at over $20 \%$ relative abundance. Functional characteristics that have been associated with Oceanospirillales members include carbon fixation, sulfur oxidation, and biofilm production in the presence of trace metals, such as copper (Little et al., 1996; Swan et al., 2011; Speck and Donachie, 2012). These roles define both the acquisition of nutrients and potential attraction or inhibition of bacterial colonization within the host. In this study, Oceanospirillales were further classified to the family level, with identifiable groups consisting of unclassified Oceanospirillales and Endozoicomonaceae. At present time, it is unclear if Endozoicomonaceae is an accepted taxon, since those same sequences were identified by RDP Classifier as Hahellaceae with $99 \%$ confidence. With that in mind, members of the family Hahellaceae (specifically genus Endozoicomonas) are widespread in the marine environment. Numerous studies have assessed Endozoicomonas in tropical and temperate corals (Sunagawa et al., 2009, 2010; Yang et al., 2010; Cardenas et al., 2012; Lee et al., 2012; Morrow et al., 2012; Apprill et al., 2013; Bayer et al., 2013a,b; Carlos et al., 2013; Correa et al., 2013; Jessen et al., 2013; La Rivière et al., 2013; Pike et al., 2013; Ransome et al., 2014; Roder et al., 2015), as well as sea slug (Kurahashi and Yokota, 2007) and sponge species (Nishijima et al., 2013; Rua et al., 2014). Because Endozoicomonas are both common and highly abundant in healthy tropical corals species, relationships between these bacteria and their hosts have been thoroughly examined. Functional characteristics include nitrate reduction, chemotactic activity, and production of antimicrobial compounds (Kurahashi and Yokota, 2007; Rua et al., 2014; Tout et al., 2015). While members of the family Hahellaceae are common in tropical and temperate environments, they do not appear to be common in deep-sea corals. Few studies have observed bacteria classified under Hahellaceae in deep (>100 m) cold-water corals (Hansson et al., 2009; Kellogg et al., 2009; Van Bleijswijk et al., 2015). The symbiotic relationships between Hahellaceae and zooxanthellae are thought to be one of the driving influences of their abundance and presence in tropical corals (Pantos et al., 2015). The lack of algal symbionts in deepsea corals may be why there are few Hahellaceae bacteria, if present at all, in these holobionts. In this study, members of the Hahellaceae (originally classified as Endozoicomonaceae) represent a small minority of the Oceanospirillales present $(\sim 2 \%$ in A. grandiflora samples RB.687Q5 and RB.688Q1).

Similar to Oceanospirillales, members of the order Kiloniellales were present in multiple Anthothela samples at relatively high abundance. Kiloniellales bacteria have been observed in several tropical coral species (Sharp et al., 2012; Soffer et al., 2015) as well as mussels (Cleary et al., 2015), sponges (Cleary et al., 2013), and algae (Wiese et al., 2009). Soffer et al. (2015), identified members of the order Kiloniellales at higher abundances in healthy coral Orbicella annularis than in diseased colonies, suggesting association in a beneficial capacity. Functionally, these chemoheterotrophic bacteria have been found to utilize nitrates within the metabolic process through denitrification (Wiese et al., 2009; Imhoff and Wiese, 2014).

Several contributing Proteobacteria were identified in individual Anthothela samples including Alteromondales, Caulobacterales, and Rickettsiales. Genus Moritella (order Alteromondales, family Moritellaceae) was present in A. grandiflora sample NF.17Q7 accounting for $\sim 26 \%$ relative abundance. This bacterial group is specific to marine environments and generally classified as halophilic facultative anaerobes (Stanley et al., 2005; Urakawa, 2014). Moritella isolates have been collected from a wide variety of environments ranging from deep-sea sediments (Kato et al., 1998; Nogi et al., 1998; Xu, 2003) to tropical corals (Rohwer et al., 2001; Bourne, 2005; Bourne and Munn, 2005). In cold-water coral species, Moritella sequences have been described in the scleractinian L. pertusa collected from the Gulf of Mexico (Kellogg, 2008). In the individual A. grandiflora sample RB.686Q4, members of the Caulobacterales were found at relatively high abundance $(\sim 30 \%)$. 
Recognized for their unique morphology, members of this order contain a stalk-like flagellum utilized for adhesion to adjacent surfaces, including but not limited to host organisms (Starr and Skerman, 1965). While these bacteria tend to exhibit parasitic tendencies, they have been described as facultative commensals, potentially contributing to the acquisition of nutrients through their roles in carbon cycling (Abraham et al., 1999). These free-living bacterial communities are often found throughout the water column and have been observed in several tropical corals including the gorgonian Pseudopterogorgia elisabethae (Correa et al., 2013) and acroporid species (A. granulosa, A. valida, and A. millepora; Littman et al., 2009; Ainsworth et al., 2015). While members of the group Caulobacterales have been identified in deep ocean waters (Eloe et al., 2011), no prior studies have observed Caulobacterales associated with cold-water corals.

Members of the order Rickettsiales have previously been described as opportunistic, pathogenic, and/or associated with diseased tropical corals (Peters et al., 1983; Casas et al., 2004; Garcia et al., 2013; Miller et al., 2014; Peters, 2014). While they are common in tropical corals, Rickettsiales have currently been identified in one cold-water octocoral species C. koolsae (Gray et al., 2011). In the present study, Rickettsiales were observed at low relative abundance $(\sim 2 \%)$ in only three Norfolk Canyon samples (RB.686Q5, RB.687Q5, and RB.688Q5). Because their functional characteristics are generally driven by ambient environmental fluctuations (e.g., increases in temperature and light intensity; Peters, 2014; Gignoux-Wolfsohn and Vollmer, 2015), we speculate that the opportunistic tendencies exhibited in tropical environments differ from those in cold-water environments. In this case, additional research is necessary to definitively assess the potential pathogenicity and overall functionality of these bacteria within the cold-water ecosystem.

\section{Spirochaetes}

Spirochaetes were observed as one of the primary bacteria, dominating over half of the Anthothela samples. Spirochaetes are recognized as motile free-living, facultative/obligate anaerobes (Leschine et al., 2006). Functional characteristics displayed by members of this phylum include nitrogen and carbon fixation, as well as chemotactic responses to chemical stimulants (Greenberg and Canale-Parol, 1977; Kimes et al., 2010; Baker et al., 2015; Lilburn et al., 2015). Spirochaetes are commonly found in association with invertebrates at high abundance, including species of termites (Breznak, 2002), oligochaetes (Blazejak et al., 2005), sponges (Taylor et al., 2005), and tropical corals (Casas et al., 2004; Kimes et al., 2010, 2013; Closek et al., 2014). Previous studies using clone libraries have observed Spirochaetes in association with some cold-water corals (Penn et al., 2006; Kellogg et al., 2009; Gray et al., 2011), however, they have never been identified as a dominant member of the associated bacterial community. In this study, Spirochaetes were recognized as the prevailing phyla in roughly half of the total Anthothela samples $(n=15)$.

In Anthothela samples (A. grandiflora and Anthothela sp.), genus Spirochaeta (phylum Spirochaetes) continued to dominate the bacterial groups. New representative Spirochaeta sequences from this study were compared to those of environmental and invertebrate studies where Spirochaeta sequences had been observed. Sequences associated with Anthothela samples were most closely related to sequences isolated from deep-sea water (Accession KF758585, E-value of $7 \mathrm{e}^{-165}$ ) and microbial mats (Accession DQ218325, E-value of $1 \mathrm{e}^{-161}$ ). While sequences from Anthothela corals were not closely related to those of other coral species, presence of this bacterium across all 16 samples suggests conservation at the family level. Additionally, presence of this bacterium at such a high abundance, as observed in Anthothela samples, suggests a unique microbe-host interaction specific to that coral genus.

\section{Core Microbiome}

In this study we applied a stringent approach to examine "core" conserved communities, evaluating bacterial groups present at the family (Anthothelidae), Anthothela genus, and individual species (A. grandiflora and Anthothela sp.) levels. To begin, samples were evaluated at the family and genus levels at $100 \%$ sample coverage, revealing one core-conserved bacterium present across all samples, a member of the genus Spirochaeta. As previously described, members of the phylum Spirochaetes are common throughout coral species, both tropical and coldwater (Casas et al., 2004; Penn et al., 2006; Kellogg et al., 2009; Gray et al., 2011; Kimes et al., 2013; Closek et al., 2014). These free-living nonpathogenic anaerobes are known to be capable of carbon fixation and organic carbon degradation (Baker et al., 2015). In this study, Spirochaeta was found to be one of the dominant bacterial groups, accounting for roughly $16 \%$ of the total relative abundance, thus suggesting a potentially important role within the coral microbiome.

Samples were then assessed at $90 \%$ sample coverage, particularly looking for conserved bacteria specific to Anthothela samples (Figure 4). In addition to the genus Spirochaeta, OTUs classified under the phylum Proteobacteria (orders; Oceanospirillales, Kiloniellales, and Campylobacterales) were identified. Previous studies described members of the orders Oceanospirillales and Kiloniellales as beneficial bacteria, contributing to their host system through the production of biofilm and antibacterial properties, respectively (Little et al., 1996; Swan et al., 2011). Oceanospirillales members have also been recognized for their influence in nutrient dynamics within the coral holobiont through the formation of dissolved inorganic materials produced during carbon fixation and sulfur oxidation (Swan et al., 2011). In contrast to Oceanospirillales and Kiloniellales, members of the order Campylobacterales are most commonly known for their association with coral disease (Frias-Lopez et al., 2002; Sunagawa et al., 2009; Sweet and Bythell, 2012; Vezzulli et al., 2013; Gignoux-Wolfsohn and Vollmer, 2015), but are also present in healthy corals (Sharp et al., 2012). Functionally these bacteria are well-known for their metabolic influence in nitrogen cycling and communication through bacterial quorum sensing (Kern and Simon, 2009; Golz et al., 2012).

Microbial functional genes capable of completing, or nearly completing, the nitrogen cycle have been identified in Pacific (Wegley et al., 2007) and Atlantic (Kimes et al., 2010) tropical corals. A complete nitrogen cycle has been shown 


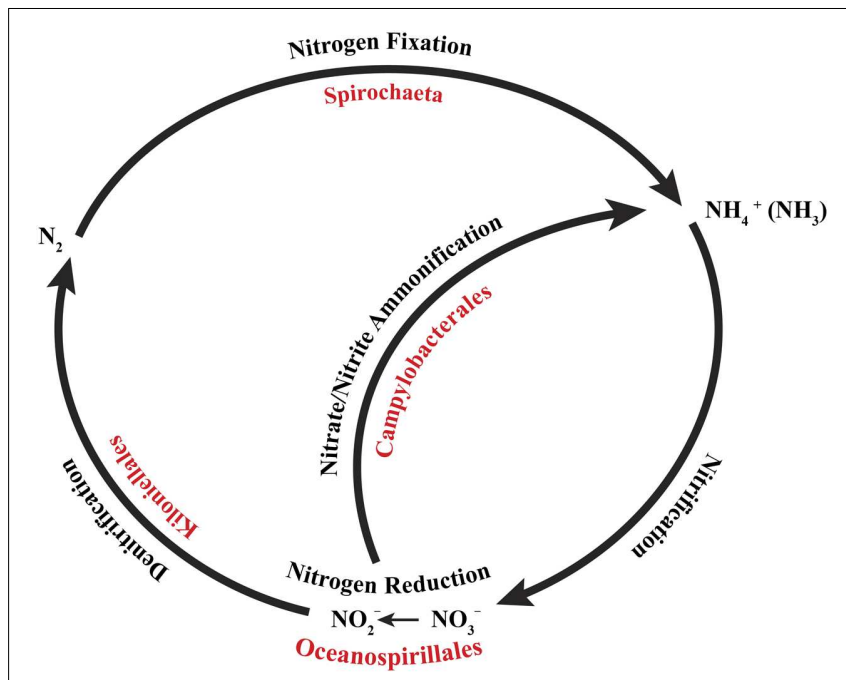

FIGURE 5 | Core bacterial groups potential roles within the nitrogen cycle. Each of the bacterial groups present within the core microbiome of Anthothela samples was previously recognized for their roles within the nitrogen cycle. This diagram illustrates a simplified overview of the bacterial groups with their possible functions. This figure was adapted from one presented in Wegley et al. (2007).

via isotope incorporation in the cold-water coral L. pertusa, including ammonium production and assimilation, nitrification, denitrification, and nitrogen fixation (Middelburg et al., 2015), however, these roles have not been definitively associated to specific microbial symbionts of the coral yet. Based on previous descriptions of nitrogen-cycling abilities in the bacterial taxa that we observed in the conserved core of Anthothela spp., we have inferred a nearly complete nitrogen cycle (Figure 5). Members of the genus Spirochaeta, identified as the most conserved bacterium, were previously recognized for their roles in nitrogen fixation (Lilburn et al., 2015). During nitrogen fixation, nitrogen gas $\left(\mathrm{N}_{2}\right)$ is converted to readily available organic compounds that may then be taken in (Zehr and Kudela, 2011). Nitrogen fixation contributes up to $1 / 3$ of the nitrogen requirement in L. pertusa (Middelburg et al., 2015), supplementing organic nitrogen obtained by capture feeding (Duineveld et al., 2012; Mueller et al., 2014). Several members of the order Campylobacterales were documented for their contributions through nitrate ammonification (Tiedje, 1988). This is the process by which nitrate is converted to ammonium, thereby recycling nitrogen back into the system (Tiedje, 1988; Simon, 2002; Rädecker et al., 2015). In the order Oceanospirillales, members have been described for their contribution as nitrate reducers, reducing nitrate to nitrite (Zehr and Kudela, 2011). Lastly, members of the order Kiloniellales, classified as chemoheterotrophic aerobic bacteria, have shown potential in the processing of molecular nitrogen through denitrification (Imhoff and Wiese, 2014). In this process, nitrates are reduced back into $\mathrm{N}_{2}$ (dinitrogen) to be utilized by nitrogenfixing bacteria. While likely important for the functioning of the Anthothela coral holobiont, the rate of nitrogen fixation observed in L. pertusa was small compared to the rates occurring in the open ocean, suggesting that cold-water corals do not significantly impact nitrogen cycling in the deep sea (Middelburg et al., 2015). This is in line with research that ascribed a similarly minor role in the nitrogen budget of coral reef ecosystems to tropical corals (Cardini et al., 2014).

Although the core microbiome of the Al. grandiflorum $(n=1)$ could not be evaluated, its bacterial community was assessed for possible functional characteristics associated with the biochemical processing of nitrogen. Similar to Anthothela samples, core members associated with Al. grandiflorum were found to belong to taxa previously documented for their metabolic abilities in nitrogen cycling. In addition to the potentially nitrogen-fixing Spirochaeta also seen in Anthothela spp., bacteria classified under families Shewanellaceae and Colwelliaceae (order Alteromonadales) have been acknowledged for their roles as nitrate reducers (Satomi, 2014; Lilburn et al., 2015). Classified as anaerobic ammonia-oxidizing bacteria, Pirellulales (phylum Planctomycetes) were thought to contribute through the removal of metabolic waste within the host microbiome (Mohamed et al., 2010). One of the end products of nitrate ammonification, ammonia, may be taken in by ammonia-oxidizing bacteria such as Pirellulales, resulting in the oxidization of ammonium and formation of nitrites (Zehr and Kudela, 2011). While members of the order Pirellulales and families Shewanellaceae and Colwelliaceae only show potential metabolic properties for a portion of the nitrogen cycle, other bacterial members may be present within Al. grandiflorum that complete the remaining functions. Further research using targeted functional genes (e.g., nifH, amoA), metagenomics, and transcriptomics are required to link these microbial roles definitively to specific bacterial community members.

\section{CONCLUSION}

Our study provides insight into the previously uncharacterized microbiome of cold-water octocorals classified under the family Anthothelidae. The two Anthothela species (A. grandiflora and Anthothela sp.) shared similar bacterial communities, in contrast to Al. grandiflorum which had a highly diverse microbiome distinct from the rest. The bacterial communities become more different as the coral taxa are more distantly related. Additionally, the bacterial composition revealed no differentiation due to geographic location (canyon of origin). Evaluations of the core microbiome at $90 \%$ revealed a conserved bacterial community associated with the Anthothela genus. Many of the core bacteria share potential metabolic functions associated with nutrient provision and properties aiding in the protection of the coral host. Overall health and proliferation of cold-water corals are dependent on capture feeding and the presence of microorganisms (Duineveld et al., 2004; Roberts et al., 2006). Members of the core microbiome of Anthothela samples were recognized for their potential roles in the uptake and remineralization of organic and inorganic material. More specifically, many of the bacterial groups present were previously documented for their roles in nitrogen cycling, including nitrogen fixation (Spirochaeta), nitrate ammonification 
(Campylobacterales), nitrate reduction (Oceanospirillales), and denitrification (Kiloniellales). Additionally, Al. grandiflorum also contained a microbial community potentially capable of various functions specific to nitrogen cycling: nitrogen fixation, nitrate reduction, and ammonia oxidation. Unfortunately, with a sample size of $n=1$, this evaluation is only a partial representation of the overall bacterial and functional diversity present within this species. Further research is necessary to investigate the microbial-host interactions, specifically the functionality of these bacterial associates and their role within the cold-water coral holobionts.

\section{AUTHOR CONTRIBUTIONS}

SL performed the DNA extractions, analysis of results, and writing of the manuscript. CK planned the experimental design and participated in the manuscript writing/editing and data analysis. SF and RC completed coral genetics and provided detailed methods and results for this analysis. SR and SB planned the research cruises, acquired samples and multibeam data, and edited the manuscript.

\section{FUNDING}

Funding for this project was provided by the U.S. Geological Survey's Ecosystems Mission Area, Environments Program through the Outer Continental Shelf study on Mid-Atlantic Canyons. Funding was sponsored by the National Oceanographic

\section{REFERENCES}

Abraham, W.-R., Strompi, C., Meyer, H., Lindhoist, S., Moore, E. R., Christ, R., et al. (1999). Phylogeny and polyphasic taxonomy of Caulobacter species. Proposal of Maricaulis gen. nov. with Maricaulis maris (Poindexter) comb. nov. as the type species, and emended description of the genera Brevundimonas and Caulobacter. J. Syst. Bacteriol. 49, 1053-1073. doi: 10.1099/00207713-49-3-1053

Ainsworth, T., Krause, L., Bridge, T., Torda, G., Raina, J. B., Zakrzewski, M., et al. (2015). The coral core microbiome identifies rare bacterial taxa as ubiquitous endosymbionts. ISME J. 9, 2261-2274. doi: 10.1038/ismej.2015.39

Ainsworth, T. D., and Hoegh-Guldberg, O. (2009). Bacterial communities closely associated with coral tissues vary under experimental and natural reef conditions and thermal stress. Aquat. Biol. 4, 289-296. doi: 10.3354/ab00102

Alsmark, C., Strese, A., Wedén, C., and Backlund, A. (2012). Microbial diversity of Alcyonium digitatum. Phytochem. Rev. 12, 531-542. doi: 10.1007/s11101-0129229-5

Altschul, S. F., Gish, W., Miller, W., Meyers, E. W., and Lipman, D. J. (1990). Basic local alignment search tool. J. Mol. Biol. 215, 403-410. doi: 10.1009/jmbi.1990.9999

Amaral-Zettler, L., Artigas, L., Baross, J., Bharathi, P., Boetius, A., Chandramohan, D., et al. (2010). "A global census of marine microbes," in Life in the World's Oceans: Diversity, Distribution and Abundance, ed. A. McIntyre (Oxford: Wiley-Blackwell), 223-247.

Apprill, A., Hughen, K., and Mincer, T. (2013). Major similarities in the bacterial communities associated with lesioned and healthy Fungiidae corals. Environ. Microbiol. 15, 2063-2072. doi: 10.1111/1462-2920.12107

Baker, B. J., Lazar, C. S., Teske, A. P., and Dick, G. J. (2015). Genomic resolution of linkages in carbon, nitrogen, and sulfur cycling among widespread estuary sediment bacteria. Microbiome 3, 14. doi: 10.1186/s40168-015-0077-6
Partnership Program and supplied by the Bureau of Ocean Energy Management (BOEM) contract number M10PC00100 (contracted to CSA Ocean Sciences, Inc.). Special thanks to G. Boland and R. Green (BOEM) for their coordination efforts, as well S. Viada (CSA) for support during the overall project. Additional funding for SL was provided by the George Lorton Endowed Fellowship through the University of South Florida, College of Marine Science as well as the Aylesworth Scholarship.

\section{ACKNOWLEDGMENTS}

The authors extend appreciation to A. Shade (Michigan State University) and the Explorations in Data Analyses for Metagenomic Advances in Microbial Ecology (EDAMAME) Workshop for critical lessons in workflow organization and bioinformatic tools. Additional thanks are extended to the captains and the crews of the NOAA ship Nancy Foster and the Kraken II ROV team as well as the NOAA ship Ronald H. Brown and Jason II ROV team. We thank K. Moore (Commonwealth Science and Industrial Research Organisation, Australia) for her insights on Anthothela taxonomy and for allowing us access to her pre-published data. Special thanks are extended to M.A. Gray (USGS) for his assistance in sample collection and advice during data analysis. M.P. Rhode (UNC-Wilmington) produced the multibeam maps of Baltimore and Norfolk canyons (Figure 1) and assisted at sea. B. Boynton (USGS) prepared final versions of the figures and M. Breitbart (USF) reviewed the manuscript. Any use of trade, firm, or product names is for descriptive purposes only and does not imply endorsement by the U.S. Government.

Barott, K., Rodriguez-Brito, B., Janouskovec, J., Marhaver, K., Smith, J., Keeling, P., et al. (2011). Microbial diversity associated with four functional groups of benthic reef algae and the reef-building coral Montastraea annularis. Environ. Microbiol. 13, 1192-1204. doi: 10.1111/j.1462-2920.2010.02419.x

Bayer, F. M. (1981). Key to the genera of Octocorallia exclusive of Pennatulacea (Coelenterata: Anthozoa), with diagnoses of new taxa. Proc. Biol. Soc. Wash. 94, 902-947.

Bayer, T., Arif, C., Ferrier-Pagès, C., Zoccola, D., Aranda, M., and Voolstra, C. R. (2013a). Bacteria of the genus Endozoicomonas dominate the microbiome of the Mediterranean gorgonian coral Eunicella cavolini. Mar. Ecol. Prog. Ser. 479, 75-84. doi: 10.3354/meps10197

Bayer, T., Neave, M. J., Alsheikh-Hussain, A., Aranda, M., Yum, L. K., Mincer, T., et al. (2013b). The microbiome of the Red Sea coral Stylophora pistillata is dominated by tissue-associated Endozoicomonas bacteria. Appl. Environ. Microbiol. 79, 4759-4762. doi: 10.1128/AEM.00695-13

Bednarz, V. N., Cardini, U., van Hoytema, N., Al-Rshaidat, M. M. D., and Wild, C. (2015). Seasonal variation in dinitrogen fixation and oxygen fluxes associated with two dominant zooxanthellate soft corals from the northern Red Sea. Mar. Ecol. Prog. Ser. 519, 141-152. doi: 10.3354/meps11091

Ben-Haim, Y., Thompson, F., Thompson, M. C., Hoste, B., Swings, J., and Rosenburg, E. (2003a). Vibrio coralliilyticus sp. nov., a temperature-dependent pathogen of the coral Pocillopora damicornis. Int. J. Syst. Evol. Microbiol. 53, 309-315. doi: 10.1099/ijs.0.02402-0

Ben-Haim, Y., Zicherman-Keren, M., and Rosenberg, E. (2003b). Temperatureregulated bleaching and lysis of the coral Pocillopora damicornis by the novel pathogen Vibrio coralliilyticus. Appl. Environ. Microbiol. 69, 4236-4242. doi: 10.1128/aem.69.7.4236-4242.2003

Berntson, E. A., Bayer, F. M., McArthur, A. G., and France, S. C. (2001). Phylogenetic relationships within the Octocorallia (Cnidaria: Anthozoa) 
based on nuclear 18S rRNA sequences. Mar. Biol. 138, 235-246. doi: $10.1007 / \mathrm{s} 002270000457$

Blazejak, A., Erseus, C., Amann, R., and Dubilier, N. (2005). Coexistence of bacterial sulfide oxidizers, sulfate reducers, and Spirochetes in a gutless worm (Oligochaeta) from the Peru margin. Appl. Environ. Microbiol. 71, 1553-1561. doi: 10.1128/AEM.71.3.1553-1561.2005

Bourne, D., and Munn, C. (2005). Diversity of bacteria associated with the coral Pocillopora damicornis from the Great Barrier Reef. Environ. Microbiol. 7, 1162-1174. doi: 10.1111/j.1462-2920.2005.00793.x

Bourne, D. G. (2005). Microbiological assessment of a disease outbreak on corals from Magnetic Island (Great Barrier Reef, Australia). Coral Reefs 24, 304-312. doi: 10.1007/s00338-005-0479-1

Bourne, D. G., and Webster, N. S. (2013). "Coral reef bacterial communities," in The Prokaryotes - Prokaryotic Communities and Ecophysiology, Vol. 4, eds E. Rosenberg, E. F. DeLong, S. Lory, E. Stackebrandt, and F. Thompson (Heidelberg: Springer Berlin), 163-187.

Bowman, J. P. (2014). "The family colwelliaceae," in The Prokaryotes Gammaproteobacteria, eds E. Rosenberg, E. F. DeLong, S. Lory, E. Stackebrandt, and F. Thompson (Heidelberg: Springer-Verlag), 179-195.

Breznak, J. A. (2002). Phylogenetic diversity and physiology of termite gut Spirochetes. Integr. Comp. Biol. 42, 313-318. doi: 10.1093/icb/42.2.313

Brinkhoff, T., Bach, G., Heidorn, T., Liang, L., Schlingloff, A., and Simon, M. (2004). Antibiotic production by a Roseobacter clade-affiliated species from the German Wadden Sea and its antagonistic effects on indigenous isolates. Appl. Environ. Microbiol. 70, 2560-2565. doi: 10.1128/aem.70.4.2560-2565.2004

Bruno, J. F., Selig, E. R., Casey, K. S., Page, C. A., Willis, B. L., Harvell, C. D., et al. (2007). Thermal stress and coral cover as drivers of coral disease outbreaks. PLoS Biol. 5:e124. doi: 10.1371/journal.pbio.0050124

Burow, L. C., Woebken, D., Marshall, I. P., Singer, S. W., Pett-Ridge, J., Prufert-Bebout, L., et al. (2014). Identification of Desulfobacterales as primary hydrogenotrophs in a complex microbial mat community. Geobiology 12, 221-230. doi: 10.1111/gbi. 12080

Caporaso, J., Kuczynski, J., Stombaugh, J., Bittinger, K., Bushman, F., Costello, E., et al. (2010). QIIME allows analysis of high-throughput community sequencing data. Nat. Methods 7, 335-336. doi: 10.1038/nmeth.f.303

Cardenas, A., Rodriguez, R. L., Pizarro, V., Cadavid, L. F., and ArevaloFerro, C. (2012). Shifts in bacterial communities of two Caribbean reef-building coral species affected by White Plague Disease. ISME J. 6, 502-512. doi: $10.1038 /$ ismej.2011.123

Cardini, U., Bednarz, V. N., Foster, R. A., and Wild, C. (2014). Benthic N2 fixation in coral reefs and the potential effects of human-induced environmental change. Ecol. Evol. 4, 1706-1727. doi: 10.1002/ece3.1050

Carlos, C., Torres, T. T., and Ottoboni, L. M. (2013). Bacterial communities and species-specific associations with the mucus of Brazilian coral species. Sci. Rep. 3, 1624. doi: 10.1038/srep01624

Casas, V., Kline, D. I., Wegley, L., Yu, Y., Breitbart, M., and Rohwer, F. (2004). Widespread association of a Rickettsiales-like bacterium with reef-building corals. Environ. Microbiol. 6, 1137-1148. doi: 10.1111/j.1462-2920.2004.00647.x

Chao, A. (1984). Nonparametric estimation of the number of classes in a population. Scand. J. Stat. 11, 265-270. doi: 10.2307/4615964

Chapman, M. G., and Underwood, A. J. (1999). Ecological patterns in multivariate assemblages: information and interpretation of negative values in ANOSIM test. Mar. Ecol. Prog. Ser. 180, 257-265. doi: 10.3354/meps180257

Claesson, M., Wang, Q., O'Sullivan, O., Greene-Diniz, R., Cole, J., Ross, R., et al. (2010). Comparison of two next-generation sequencing technologies for resolving highly complex microbiota composition using tandem variable 16S rRNA gene regions. Nucleic Acids Res. 38:e200. doi: 10.1093/nar/ gkq873

Clarke, K., and Warwick, R. (2001). Change in Marine Communities: An Approach to Statistical Analysis and Interpretation. Plymouth: PRIMER-E Ltd.

Cleary, D. F., Becking, L. E., de Voogd, N. J., Pires, A. C., Polonia, A. R., Egas, C., et al. (2013). Habitat- and host-related variation in sponge bacterial symbiont communities in Indonesian waters. FEMS Microbiol. Ecol. 85, 465-482. doi: 10.1111/1574-6941.12135

Cleary, D. F., Becking, L. E., Polonia, A. R., Freitas, R. M., and Gomes, N. C. (2015). Composition and predicted functional ecology of mussel-associated bacteria in Indonesian marine lakes. Antonie Van Leeuwenhoek 107, 821-834. doi: 10.1007/s10482-014-0375-1
Closek, C. J., Sunagawa, S., DeSalvo, M. K., Piceno, Y. M., DeSantis, T. Z., Brodie, E. L., et al. (2014). Coral transcriptome and bacterial community profiles reveal distinct Yellow Band Disease states in Orbicella faveolata. ISME J. 8, 2411-2422. doi: 10.1038/ismej.2014.85

Correa, H., Haltli, B., Duque, C., and Kerr, R. (2013). Bacterial communities of the gorgonian octocoral Pseudopterogorgia elisabethae. Microb. Ecol. 66, 972-985. doi: 10.1007/s00248-013-0267-3

Coursolle, D., and Gralnick, J. A. (2012). Reconstruction of extracellular respiratory pathways for Iron (III) reduction in Shewanella oneidensis Strain MR-1. Front. Microbiol. 3:56. doi: 10.3389/fmicb.2012.00056

DeSantis, T. Z., Hugenholtz, P., Larsen, N., Rojas, M., Brodie, E. L., Keller, K., et al. (2006). Greengenes, a chimera-checked 16S rRNA gene database and workbench compatible with ARB. Appl. Environ. Microbiol. 72, 5069-5072. doi: 10.1128/AEM.03006-05

Duineveld, G. C. A., Jeffreys, R. M., Lavaleye, M. S. S., Davies, A. J., Bergman, M. J. N., Watmough, T., et al. (2012). Spatial and tidal variation in food supply to shallow cold-water coral reefs of the Mingulay Reef complex (Outer Hebrides, Scotland). Mar. Ecol. Prog. Ser. 444, 97-115. doi: 10.3354/meps09430

Duineveld, G. C. A., Lavaleye, M. S. S., and Berghuis, E. M. (2004). Particle flux and food supply to a seamount cold-water coral community (Galicia Bank, NW Spain). Mar. Ecol. Prog. Ser. 227, 13-23. doi: 10.3354/meps277013

Edgar, R. C. (2010). Search and clustering orders of magnitude faster than BLAST. Bioinformatics 26, 2460-2461. doi: 10.1093/bioinformatics/btq461

Eloe, E. A., Shulse, C. N., Fadrosh, D. W., Williamson, S. J., Allen, E. E., and Bartlett, D. H. (2011). Compositional differences in particle-associated and free-living microbial assemblages from an extreme deep-ocean environment. Environ. Microbiol. Rep. 3, 449-458. doi: 10.1111/j.1758-2229.2010.00223.x

France, S. C. (2007). Genetic analysis of bamboo corals (Cnidaria: Octocorallia: Isididae): does lack of colony branching distinguish (Lepidisis from Keratoisis? Bull. Mar. Sci. 81, 323-333.

Frias-Lopez, J., Zerkle, A. L., Bonheyo, G. T., and Fouke, B. W. (2002) Partitioning of bacterial communities between seawater and healthy, Black Band Diseased, and dead coral surfaces. Appl. Environ. Microbiol. 68, 22142228. doi: $10.1128 / \mathrm{aem} \cdot 68.5 .2214-2228.2002$

Fukuyama, J., McMurdie, P., Dethlefsen, L., Relman, D., and Holmes, S. (2012). Comparisons of distance methods form combining covariates and abundances in microbiome studies. Pac. Symp. Biocomput. 1, 213-224. doi: $10.1142 / 9789814366496 \_0021$

Galkiewicz, J. P., and Kellogg, C. A. (2008). Cross-kingdom amplification using bacteria-specific primers: complications for studies of coral microbial ecology. Appl. Environ. Microbiol. 74, 7828-7831. doi: 10.1128/AEM.01303-08

Galkiewicz, J. P., Pratte, Z. A., Gray, M. A., and Kellogg, C. A. (2011). Characterization of culturable bacteria isolated from the cold-water coral Lophelia pertusa. FEMS Microbiol. Ecol. 77, 333-346. doi: 10.1111/j.15746941.2011.01115.x

Garcia, G. D., Gregoracci, G. B., Santos Ede, O., Meirelles, P. M., Silva, G. G., Edwards, R., et al. (2013). Metagenomic analysis of healthy and white plagueaffected Mussismilia braziliensis corals. Microb. Ecol. 65, 1076-1086. doi: 10.1007/s00248-012-0161-4

Garrity, G. M., Bell, J., and Lilburn, T. (2005). "Order VI. Legionellales ord. nov," in Bergey's Manual of Systematic Bacteriology: The Gammaproteobacteria, Vol. 2, eds D. J. Brenner, N. R. Krieg, and J. T. Staley (New York, NY: Springer), 210.

Gignoux-Wolfsohn, S. A., and Vollmer, S. V. (2015). Identification of candidate coral pathogens on White Band Disease-infected staghorn coral. PLOS ONE 10:e0134416. doi: 10.1371/journal.pone. 0134416

Golz, G., Sharbati, S., Backert, S., and Alter, T. (2012). Quorum sensing dependent phenotypes and their molecular mechanisms in Campylobacterales. Eur. J. Microbiol. Immunol. 2, 50-60. doi: 10.1556/EuJMI.2.2012.1.8

Gray, M. A., Stone, R. P., McLaughlin, M. R., and Kellogg, C. A. (2011). Microbial consortia of gorgonian corals from the Aleutian Islands. FEMS Microbiol. Ecol. 76, 109-120. doi: 10.1111/j.1574-6941.2010.01033.x

Greenberg, E., and Canale-Parol, E. (1977). Chemotaxis in Spirochata aurantia. J. Bacteriol. 130, 485-494.

Grover, R., Ferrier-Pagès, C., Maguer, J.-F., Ezzat, L., and Fine, M. (2014). Nitrogen fixation in the mucus of Red Sea corals. J. Exp. Biol. 217, 3962-3963. doi: $10.1242 /$ jeb. 111591

Hall, T. (1998). BioEdit: a user-friendly biological sequence alignment editor and analysis program for Windows 95/98/NT. Nucl. Acids Symp. Ser. 41, 95-98. 
Hall-Spencer, J., Pike, J., and Munn, C. B. (2007). Diseased affect cold-water corals too: Eunicella verrucosa (Cnidaria: Gorgonacea) necrosis in SW England. Dis. Aquat. Organ. 76, 87-97. doi: 10.3354/dao076087

Hansson, L., Agis, M., Maier, C., and Weinbauer, M. G. (2009). Community composition of bacteria associated with cold-water coral Madrepora oculata: within and between colony variability. Mar. Ecol. Prog. Ser. 397, 89-102. doi: 10.3354/meps08429

Hau, H. H., and Gralnick, J. A. (2007). Ecology and biotechnology of the genus Shewanella. Ann. Rev. Microbiol. 61, 237-258. doi: 10.1146/annurev.micro.61.080706.093257

Imhoff, J. F., and Wiese, J. (2014). "The order Kiloniellales," in The Prokaryotes, eds E. Rosenberg, E. F. DeLong, S. Lory, E. Stackebrandt, and C. C. Thompson (Berlin: Springer), 301-306.

Jaekel, U., Musat, N., Adams, B., Kuypers, M., Grundmann, O., and Musat, F. (2013). Anaerobic degredation of propane and butane by sulfate-reducing bacteria enriched from marine hydrocarbon cold-seeps. ISME J. 7, 885-895. doi: 10.1038/ismej.2012.159

Jessen, C., Villa Lizcano, J. F., Bayer, T., Roder, C., Aranda, M., Wild, C., et al. (2013). In-situ effects of eutrophication and overfishing on physiology and bacterial diversity of the Red Sea coral Acropora hemprichii. PLoS ONE 8:e62091. doi: 10.1371/journal.pone.0062091

Kato, C., Li, L., Nogi, Y., Nakamura, Y., Tamaoka, J., and Horikoshi, K. (1998). Extremely barophilic bacteria isolated from the Mariana Trench, Challenger Deep, at a depth of 11,000 meters. Appl. Environ. Microbiol. 64, 1510-1513.

Kellogg, C. A. (2008). "Microbial ecology of Lophelia pertusa in the Northern Gulf of Mexico," in Characterization of Northern Gulf of Mexico Deepwater Hard Bottom Communities with Emphasis on Lophelia Coral - Lophelia Reef Megafaunal Community Structure, Biotopes, Genetics, Microbial Ecology, and Geology (2004-2006): USGS Open-File Report 2008-1148, OCS Study MMS 2008-2015, eds K. J. Sulak, M. Randall, K. E. Luke, A. D. Norem, J. M. Miller (New Orleans, LA: U.S. Geological Survey and US Minerals Management Services), 6.1-6.42.

Kellogg, C. A., and Lawler, S. N. (2015). Cold-water coral microbiomes (Anthothela spp.) from Baltimore and Norfolk Canyons: raw and processed data. U.S. Geological Survey Data Release. Available at: http://dx.doi.org/10.5066/F7C Z356K

Kellogg, C. A., Lisle, J. T., and Galkiewicz, J. P. (2009). Culture-independent characterization of bacterial communities associated with the cold-water coral Lophelia pertusa in the northeastern Gulf of Mexico. Appl. Environ. Microbiol. 75, 2294-2303. doi: 10.1128/AEM.02357-08

Kern, M., and Simon, J. (2009). Electron transport chains and bioenergetics of respiratory nitrogen metabolism in Wolinella succinogenes and other Epsilonproteobacteria. Biochim. Biophys. 1787, 646-656. doi: 10.1016/j.bbabio.2008.12.010

Kim, S. J., Park, S. J., Oh, Y. S., Lee, S. A., Shin, K. S., Roh, D. H., et al. (2012). Shewanella arctica sp. nov., an iron-reducing bacterium isolated from Arctic marine sediment. Int. J. Syst. Evol. Microbiol. 62, 1128-1133. doi: 10.1099/ijs.0.031401-0

Kimes, N. E., Johnson, W. R., Torralba, M., Nelson, K. E., Weil, E., and Morris, P. J. (2013). The Montastraea faveolata microbiome: ecological and temporal influences on a Caribbean reef-building coral in decline. Environ. Microbiol. 15, 2082-2094. doi: 10.1111/1462-2920.12130

Kimes, N. E., Van Nostrand, J. D., Weil, E., Zhou, J., and Morris, P. J. (2010). Microbial functional structure of Montastraea faveolata, an important Caribbean reef-building coral, differs between healthy and yellow-band diseased colonies. Environ. Microbiol. 12, 541-556. doi: 10.1111/j.14622920.2009.02113.x

Koren, O., and Rosenberg, E. (2006). Bacteria associated with mucus and tissues of the coral Oculina patagonica in summer and winter. Appl. Environ. Microbiol. 72, 5254-5259. doi: 10.1128/AEM.00554-06

Krediet, C. J., Ritchie, K. B., Paul, V. J., and Teplitski, M. (2013). Coral-associated micro-organisms and their roles in promoting coral health and thwarting diseases. Proc. Biol. Sci. 280, 20122328. doi: 10.1098/rspb.2012.2328

Kuever, J., Rainey, F. A., and Widdel, F. (2005). “Order III. Desulfobacterales ord. nov," in Bergey's Manual of Systematic Bacteriology: The Proteobacteria, Vol. 2, eds D. J. Brenner, N. R. Krieg, and J. T. Staley (New York, NY: Springer).

Kunin, V., Engelbrektson, A., Ochman, H., and Hugenholtz, P. (2010). Wrinkles in the rare biosphere: pyrosequencing errors can lead to artificial inflation of diversity estimates. Environ. Microbiol. 12, 118-123. doi: 10.1111/j.14622920.2009.02051.x

Kurahashi, M., and Yokota, A. (2007). Endozoicomonas elysicola gen. nov., sp. nov., a Gamma-proteobacterium isolated from the sea slug Elysia ornata. Syst. Appl. Microbiol. 30, 202-206. doi: 10.1016/j.syapm.2006.07.003

Kushmaro, A., Banin, E., Loya, Y., Stackebrandt, E., and Rosenberg, E. (2001). Vibrio shiloi sp. nov., the causative agent of bleaching of the coral Oculina patagonica. Int. J. Syst. Evol. Microbiol. 51, 1383-1388. doi: 10.1099/0020771351-4-1383

La Rivière, M., Garrabou, J., and Bally, M. (2015). Evidence for host specificity among dominant bacterial symbionts in temperate gorgonian corals. Coral Reefs 1, 1-12. doi: 10.1007/s00338-015-1334-7

La Rivière, M., Roumagnac, M., Garrabou, J., and Bally, M. (2013). Transient shifts in bacterial communities associated with the temperate gorgonian Paramuricea clavata in the Northwestern Mediterranean Sea. PLoS ONE 8:e57385. doi: 10.1371/journal.pone.0057385

Lampert, Y., Kelman, D., Dubinsky, Z., Nitzan, Y., and Hill, R. T. (2006). Diversity of culturable bacteria in the mucus of the Red Sea coral Fungia scutaria. FEMS Microbiol. Ecol. 58, 99-108. doi: 10.1111/j.1574-6941.2006.00136.x

Lee, O. O., Yang, J., Bougouffa, S., Wang, Y., Batang, Z., Tian, R., et al. (2012). Spatial and species variations in bacterial communities associated with corals from the Red Sea as revealed by pyrosequencing. Appl. Environ. Microbiol. 78, 7173-7184. doi: 10.1128/AEM.01111-12

Lema, K., Willis, B., and Bourne, D. (2012). Corals form characteristic associations with symbiotic nitrogen-fixing bacteria. Appl. Environ. Microbiol. 78, 31363144. doi: 10.1128/AEM.07800-11

Lema, K., Willis, B., and Bourne, D. (2014). Amplicon pyrosequencing reveals spatial and temporal consistency in diazotroph assemblages of the Acropora millepora microbiome. Environ. Microbiol. 16, 3345-3349. doi: 10.1111/14622920.12366

Leschine, S., Paster, B. J., and Canale-Parola, E. (2006). "Free-living saccharolytic spirochetes: the genus Spirochaeta," in The Prokaryotes, eds M. Dworkin, S Falkow, E. Rosenberg, K. Schleifer, and E. Stackebrandt (New York, NY: Springer), 195-210.

Lilburn, T., Kim, K., Ostrom, N., Byzek, K., Leadbetter, J., and Breznak, J. (2015). Nitrogen fixation by symbiotic and free-living spirochetes. Sci. Rep. 292, 2495 2498. doi: 10.1126/science.1060281

Little, B., Wagner, P., Angell, P., and White, D. (1996). Correlation between localized anodic areas and Oceanospirillum biofilms on Copper. Int. Biodeterior. Biodegradation 37, 152-162. doi: 10.1016/S0964-8305(96) 00014-5

Littman, R. A., Willis, B. L., Pfeffer, C., and Bourne, D. G. (2009). Diversities of coral-associated bacteria differ with location, but not species, for three acroporid corals on the Great Barrier Reef. FEMS Microbiol. Ecol. 68, 152-163. doi: 10.1111/j.1574-6941.2009.00666.x

Lozupone, C., and Knight, R. (2005). UniFrac: a new phylogenetic method for comparing microbial communities. Appl. Environ. Microbiol. 71, 8228-8235. doi: 10.1128/AEM.71.12.8228-8235.2005

Lumsden, S. E., Hourigan, T. F., Dorr, G., Bruckner, A. W., Brooke, S., and Stone, R. P. (2007). The State of Deep Coral Ecosystems of the United States: 2007 NOAA Technical Memorandum CRCP - 3. Silver Spring, MD: NOAA, 1-365.

Marchesi, J. R., Sato, T., Weightman, A. J., Martin, T., Fry, J. C., Hiom, S., et al. (1998). Design and evaluation of useful bacterium-specific PCR primers that amplify gene coding for bacterial 16S rRNA. Appl. Environ. Microbiol. 64, 2332-2333.

McFadden, C. S., Benayahu, Y., Pante, E., Thoma, J. N., Nevarez, P. A., and France, S. C. (2011). Limitations of mitochondrial gene barcoding in Octocorallia. Mol. Ecol. Resour. 11, 19-31. doi: 10.1111/j.1755-0998.2010.02875.x

Meron, D., Rodolfo-Metalpa, R., Cunning, R., Baker, A. C., Fine, M., and Banin, E. (2012). Changes in coral microbial communities in response to a natural pH gradient. ISME J. 6, 1775-1785. doi: 10.1038/ismej. 2012.19

Middelburg, J., Mueller, C., Veuger, B., Larsson, A., Form, A., and van Oevelen, D. (2015). Discovery of symbiotic nitrogen fixation and chemoautotrophy in cold-water corals. Sci. Rep. 5, 17962. doi: 10.1038/srep17962

Miller, M., Lohr, K., Cameron, C., Williams, D., and Peters, E. (2014). Disease dynamics and potential mitigation among restored and wild stagehorn coral, Acropora cervicornis. PeerJ 2:e541. doi: 10.7717/peerj.541 
Mohamed, N. M., Saito, K., Tal, Y., and Hill, R. T. (2010). Diversity of aerobic and anaerobic ammonia-oxidizing bacteria in marine sponges. ISME J. 4, 38-48. doi: 10.1038/ismej.2009.84

Morrow, K. M., Moss, A. G., Chadwick, N. E., and Liles, M. R. (2012). Bacterial associates of two Caribbean coral species reveal species-specific distribution and geographic variability. Appl. Environ. Microbiol. 78, 6438-6449. doi: 10.1128/AEM.01162-12

Mueller, C. E., Larsson, A. I., Veuger, B., Middelburg, J. J., and van Oevelen, D. (2014). Opportunistic feeding on various organic food sources by the cold-water coral Lophelia pertusa. Biogeosciences 11, 123-133. doi: 10.5194/bg-11-123-2014

Neulinger, S., Gartner, A., Jarnegren, J., Ludvigsen, M., Lochte, K., and Dullo, W. C. (2009). Tissue-associated "Candidatus Mycoplasma Corallicola" and filamentous bacteria on the cold-water coral Lophelia pertusa (Scleractinia). Appl. Environ. Microbiol. 75, 1437-1444. doi: 10.1128/AEM.01781-08

Neulinger, S. C., Jarnegren, J., Ludvigsen, M., Lochte, K., and Dullo, W.-C. (2008). Phenotype-specific bacterial communities in the cold-water coral Lophelia pertusa (Scleractinia) and their implications for the coral's nutrition, health, and distribution. Appl. Environ. Microbiol. 74, 7272-7285. doi: 10.1128/AEM.01777-08

Nishijima, M., Adachi, K., Katsuta, A., Shizuri, Y., and Yamasato, K. (2013). Endozoicomonas numazuensis sp. nov., a Gammaproteobacterium isolated from marine sponges, and emended description of the genus Endozoicomonas Kurahashi and Yokota, 2007. Int. J. Syst. Evol. Microbiol. 63, 709-714. doi: 10.1099/ijs.0.042077-0

Nissimov, J., Rosenberg, E., and Munn, C. B. (2009). Antimicrobial properties of resident coral mucus bacteria of Oculina patagonica. FEMS Microbiol. Lett. 292, 210-215. doi: 10.1111/j.1574-6968.2009.01490.x

Nogi, Y., Kato, C., and Horikoshi, K. (1998). Moritella japonica sp. mov., a novel barophillic bacterium isolated from Japan Trench sediment. J. Gen. Appl. Microbiol. 44, 289-295. doi: 10.2323/jgam.44.289

Oksanen, J., Blancket, F. G., Kindt, R., Legendre, P., Minchin, P. R., O’Hara, R., et al. (2015). Vegan: Community Ecology Package. Available at: http://CRAN.Rproject.org/package=vegan [accessed May 12, 2015].

Olson, N. D., Ainsworth, T. D., Gates, R. D., and Takabayashi, M. (2009). Diazotrophic bacteria associated with Hawaiian Montipora corals: diversity and abundance in correlation with symbiontic dinoflagellates. J. Exp. Mar. Biol. Ecol. 371, 140-146. doi: 10.1016/j.jembe.2009.01.012

Olson, N. D., and Lesser, M. P. (2013). Diazotrophic diversity in the Caribbean coral, Montastraea cavernosa. Arch. Microbiol. 195, 853-859. doi: 10.1007/s00203-013-0937-z

Pante, E., Abdelkrim, J., Viricel, A., Gey, D., France, S. C., Boisselier, M. C., et al. (2015). Use of RAD sequencing for delimiting species. Heredity 114, 450-459. doi: $10.1038 /$ hdy.2014.105

Pante, E., and France, S. C. (2010). Pseudochrysogorgia bellona n. gen., n. sp.: a new genus and species of chrysogorgiid octocoral (Coelenterata, Anthozoa) from the Coral Sea. Zoosystema 32, 595-612. doi: 10.5252/z2010n4a4

Pantos, O., Bongaerts, P., Dennis, P., Tyson, G., and Hoegh-Guldberg, O. (2015). Habitat-specific environmental conditions primarily control the microbiomes of the coral Seriatopora hystrix. ISME J. 9, 1916-1927. doi: 10.1038/ismej.2015.3

Pantos, O., Cooney, R. P., Tissier, M. D. L., Braer, M. R., Donnell, A. G., and Bythell, J. C. (2003). The bacterial ecology of a plague-like disease affecting the Caribbean coral Montastrea annularis. Environ. Microbiol. 5, 370-382. doi: 10.1046/j.1462-2920.2003.00427.x

Penn, K., Wu, D., Eisen, J. A., and Ward, N. (2006). Characterization of bacterial communities associated with deep-sea corals on Gulf of Alaska seamounts. Appl. Environ. Microbiol. 72, 1680-1683. doi: 10.1128/AEM.72.2.16801683.2006

Peters, E. (2014). "A Rickettsiales-like (?) bacterium is responsible for the tissue loss diseases of Caribbean acroporid corals," in Proceedings of the Ocean Science Meeting 2014, February 23-28, Honolulu, HI. Available at: http://www.sgmeet.com/osm2014/viewabstract.asp?

Peters, E., Oprandy, J., and Yevich, P. (1983). Possible causal agent of "White Band Disease" in Caribbean Acroporid corals. J. Invertebr. Pathol. 41, 394-396. doi: 10.1016/0022-2011(83)90260-4

Pike, R. E., Haltli, B., and Kerr, R. G. (2013). Description of Endozoicomonas euniceicola sp. nov. and Endozoicomonas gorgoniicola sp. nov., bacteria isolated from the octocorals Eunicea fusca and Plexaura sp., and an emended description of the genus Endozoicomonas. Int. J. Syst. Evol. Microbiol. 63, 4294-4302. doi: 10.1099/ijs.0.051490-0

Pratte, Z. A. (2013). Microbial functional genes associated with coral health and disease. Dis. Aquat. Organ. 107, 161-171. doi: 10.3354/ dao02664

Price, N. M., Dehal, P., and Arkin, A. (2010). FastTree 2 - Approximately maximum-liklihood trees for large alignments. PLOS ONE 5:e9490. doi: 10.1371/journal.pone.0009490

Quince, C., Lanzen, A., Davenport, R. J., and Turnbaugh, P. J. (2011). Removing noise from pyrosequenced amplicons. BMC Bioinformatics 12:38. doi: 10.1186/1471-2105-12-38

R Development Core Team (2014). R: A Language and Environment for Statistical Computing. Vienna: R Foundation for Statistical Computing.

Rädecker, N., Meyer, F. W., Bednarz, V. N., Cardini, U., and Wild, C. (2014). Ocean acidification rapidly reduces dinitrogen fixation associated with the hermatypic coral Seriatopora hystrix. Mar. Ecol. Prog. Ser. 511, 297-302. doi: 10.3354/meps10912

Rädecker, N., Pogoreutz, C., Voolstra, C. R., Wiedenmann, J., and Wild, C. (2015). Nitrogen cycling in corals: the key to understanding holobiont functioning? Trends Microbiol. 23, 490-497. doi: 10.1016/j.tim.2015.03.008

Raina, J. B., Tapiolas, D., Willis, B. L., and Bourne, D. G. (2009). Coral-associated bacteria and their role in the biogeochemical cycling of sulfur. Appl. Environ. Microbiol. 75, 3492-3501. doi: 10.1128/AEM.02567-08

Ransome, E., Rowley, S. J., Thomas, S., Tait, K., and Munn, C. B. (2014). Disturbance to conserved bacterial communities in the cold-water gorgonian coral Eunicella verrucosa. FEMS Microbiol. Ecol. 90, 404-416. doi: 10.1111/1574-6941.12398

Reichenbach, H. (1999). The ecology of Myxobacteria. Environ. Microbiol. 1, 15-21. doi: 10.1046/j.1462-2920.1999.00016.x

Reichenbach, H., and Dworkin, M. (1992). "The Myxobacteria," in The Prokaryotes, Vol. 2, eds A. Balows, H. Truper, M. Dworkin, W. Harder, and K. Schleifer (Berlin: Springer-Verlag), 3416-3487.

Reshef, L., Koren, O., Loya, Y., Zilber-Rosenberg, I., and Rosenberg, E. (2006). The coral probiotic hypothesis. Environ. Microbiol. 8, 2068-2073. doi: 10.1111/j.1462-2920.2006.01148.x

Rideout, J. R., He, Y., Navas-Molina, J. A., Walters, W. A., Ursell, L. K., Gibbons, S. M., et al. (2014). Subsampled open-reference clustering creates consistent, comprehensive OTU definitions and scales to billions of sequences. PeerJ 2:e545. doi: 10.7717/peerj.545

Ritchie, K. B. (2006). Regulation of microbial populations by coral surface mucus and mucus-associated bacteria. Mar. Ecol. Prog. Ser. 322, 1-14. doi: $10.3354 /$ meps322001

Roberts, J. M., Wheeler, A. J., and Freiwald, A. (2006). Reefs of the deep: the biology and geology of cold-water coral ecosystems. Science 312, 543-547. doi: $10.1126 /$ science. 1119861

Roberts, S., and Hirshfield, M. (2004). Deep-sea corals: out of sight, but no longer out of mind. Front. Ecol. Environ. 2, 123-130. doi: 10.2307/3868237

Roder, C., Arif, C., Daniels, C., Weil, E., and Voolstra, C. R. (2014). Bacterial profiling of White Plague Disease across corals and oceans indicates a conserved and distinct disease microbiome. Mol. Ecol. 23, 965-974. doi: $10.1111 /$ mec. 12638

Roder, C., Bayer, T., Aranda, M., Kruse, M., and Voolstra, C. R. (2015). Microbiome structure of the fungid coral Ctenactis echinata aligns with environmental differences. Mol. Ecol. 24, 3501-3511. doi: 10.1111/mec.13251

Rohwer, F., Breitbart, M., Jara, J., Azam, F., and Knowlton, N. (2001). Diversity of bacteria associated with the Caribbean coral Montastraea franksi. Coral Reefs 20, 85-91. doi: 10.1007/s003380100138

Rohwer, F., Seguritan, V., Azam, F., and Knowlton, N. (2002). Diversity and distribution of coral-associated bacteria. Mar. Ecol. Progr. Ser. 243, 1-10. doi: $10.3354 /$ meps 243001

Rosenberg, E., Koren, O., Reshef, L., Efrony, R., and Zilber-Rosenberg, I. (2007). The role of microorganisms in coral health, disease and evolution. Nat. Rev. Microbiol. 5, 355-362. doi: 10.1038/nrmicro1635

Rua, C. P., Trindade-Silva, A. E., Appolinario, L. R., Venas, T. M., Garcia, G. D., Carvalho, L. S., et al. (2014). Diversity and antimicrobial potential of culturable heterotrophic bacteria associated with the endemic marine sponge Arenosclera brasiliensis. PeerJ. 2:e419. doi: 10.7717/peerj.419 
Satomi, M. (2014). “The Family Shewanellaceae," in The Prokaryotes Gammaproteobacteria, eds E. Rosenberg, E. F. DeLong, S. Lory, E. Stackebrandt, and F. Thompson (Berlin: Springer_Verlag), 597-625.

Schottner, S., Hoffmann, F., Wild, C., Rapp, H. T., Boetius, A., and Ramette, A. (2009). Inter- and intra-habitat bacterial diversity associated with cold-water corals. ISME J. 3, 756-759. doi: 10.1038/ismej.2009.15

Shade, A., and Handelsman, J. (2012). Beyond the Venn diagram: the hunt for a core microbiome. Environ. Microbiol. 14, 4-12. doi: 10.1111/j.14622920.2011.02585.x

Shannon, C. (1948). A mathematical theory of communication. Bell Syst. Tech. J. 27, 379-423. doi: 10.1002/j.1538-7305.1948.tb00917.x

Sharp, K. H., Distel, D., and Paul, V. (2012). Diversity and dynamics of bacterial communities in early life stages of the Caribbean coral Porites astreoides. ISME J. 6, 790-801. doi: 10.1038/ismej.2011.144

Shashar, N., Cohen, Y., Loya, Y., and Sar, N. (1994). Nitrogen fixation (acetylene reducation) in stony corals: evidence for coral-bacteria interactions. Mar. Ecol. Prog. Ser. 111, 259-264. doi: 10.3354/meps111259

Shnit-Orland, M., and Kushmaro, A. (2009). Coral mucus-associated bacteria: a possible first line of defense. FEMS Microbiol. Ecol. 67, 371-380. doi: 10.1111/j.1574-6941.2008.00644.x

Shnit-Orland, M., Sivan, A., and Kushmaro, A. (2010). Shewanella corallii sp. nov., a marine bacterium isolated from a Red Sea coral. Int. J. Syst. Evol. Microbiol. 60, 2293-2297. doi: 10.1099/ijs.0.015768-0

Simister, R., Antzis, E., and White, H. (2015). Examining the diversity of microbes in deep-sea coral community impacted by the Deepwater Horizon oil spill. Deep Sea Res. Part II Top. Stud. Oceanogr. 1, 1-10. doi: 10.1016/j.dsr2.2015. 01.010

Simon, J. (2002). Enzymology and bioenergetics of respiratory nitrite ammonification. FEMS Microbiol. Rev. 26, 286-309. doi: $10.1111 /$ j.1574-6976.2002

Simpson, E. (1949). Measurment of diversity. Nature 163, 688. doi: $10.1038 / 163688 \mathrm{a} 0$

Soffer, N., Zaneveld, J., and Vega Thurber, R. (2015). Phage-bacteria network analysis and its implication for the understanding of coral disease. Environ. Microbiol. 17, 1203-1218. doi: 10.1111/1462-2920.12553

Speck, M., and Donachie, S. (2012). Widespread Oceanospirillaceae bacteria in Porites spp. J. Mar. Biol. 2012, 1-7. doi: 10.1155/2012/746720

Stamatakis, A., Hoover, P., and Rougemont, J. (2008). A rapid bootstrap algorithm for the RAxML web servers. Syst. Biol. 57, 758-771. doi: $10.1080 / 10635150802429642$

Stanley, G., Boone, D. R., Brenner, D. J., Vos, P. D., Garrity, G. M., Goodfellow, M., et al. (2005). Genus X. Moritella, Bergey's, Vol. 2. New York, NY: Springer.

Starr, M., and Skerman, V. (1965). Bacterial diversity: the natural history of selected morphologically unusual bacteria. Annu. Rev. 19, 407-454. doi: 10.1146/annurev.mi.19.100165.002203

Sunagawa, S., DeSantis, T. Z., Piceno, Y. M., Brodie, E. L., DeSalvo, M. K., Voolstra, C. R., et al. (2009). Bacterial diversity and White Plague disease-associated community changes in the Caribbean coral Montastraea faveolata. ISME J. 3, 512-521. doi: 10.1038/ismej.2008.131

Sunagawa, S., Woodley, C. M., and Medina, M. (2010). Threatened corals provide underexplored microbial habitats. PLoS ONE 5:e9554. doi: 10.1371/journal.pone.0009554

Sussman, M., Willis, B. L., Victor, S., and Bourne, D. G. (2008). Coral pathogens identified for White Syndrome (WS) epizootic in Indo-Pacific. PLoS ONE 3:e2393. doi: 10.1371/journal.pone.0002393.g001

Swan, B., Martinez-Garcia, M., Preston, C., Sczyrba, A., Woyke, T., Lamy, D., et al. (2011). Potential for chemolithoautotrophy among ubiguitous bacteria lineages in the dark ocean. Sci. Rep. 333, 1296-1299. doi: 10.1126/science. 1203690

Sweet, M., and Bythell, J. (2012). Ciliate and bacterial communities associated with White Syndrome and Brown Band Disease in reef-building corals. Environ. Microbiol. 14, 2184-2199. doi: 10.1111/j.1462-2920.2012. 02746.x

Sweet, M., Croquer, A., and Bythell, J. (2010). Bacterial assemblages differ between compartments within the coral holobiont. Coral Reefs 30, 39-52. doi: 10.1007/s00338-010-0695-1

Taylor, M. W., Schupp, P. J., de Nys, R., Kjelleberg, S., and Steinberg, P. D. (2005). Biogeography of bacteria associated with the marine sponge
Cymbastela concentrica. Environ. Microbiol. 7, 419-433. doi: 10.1111/j.14622920.2004.00711.x

Thompson, F. L., Barash, Y., Sawabe, T., Sharon, G., Swings, J., and Rosenberg, E. (2006). Thalassomonas loyana sp. nov., a causative agent of the White Plaguelike disease of corals on the Eilat coral reef. Int. J. Syst. Evol. Microbiol. 56, 365-368. doi: 10.1099/ijs0.63800-0

Thompson, J. D., Higgins, D. G., and Gibson, T. J. (1994). CLUSTAL W: inproving the sensitivity of progressive multiple sequence alignment through sequence weighting, position-specific gap penalties and weight matrix choice. Nucleic Acids Res. 22, 4673-4680. doi: 10.1093/nar/22.22.4673

Thurber, R. V., Willner-Hall, D., Rodriguez-Mueller, B., Desnues, C., Edwards, R. A., Angly, F. E., et al. (2009). Metagenomic analysis of stressed coral holobionts. Environ. Microbiol. 11, 2148-2163. doi: 10.1111/j.14622920.2009.01935.x

Tiedje, J. (1988). "Ecology of denitrification and dissimilatory nitrate reduction to ammonium," in Environmental Microbiology of Anaerobes, ed. A. Zehnder (New York, NY: John Wiley and Sons).

Toren, A., Landau, L., Kushmaro, A., Loya, Y., and Rosenberg, E. (1998). Effect of temperature on adhesion of Vibrio Strain AK-1 to Oculina patagonica and on coral bleaching. Appl. Environ. Microbiol. 64, 1379-1384.

Tout, J., Jeffries, T. C., Petrou, K., Tyson, G. W., Webster, N. S., Garren, M., et al. (2015). Chemotaxis by natural populations of coral reef bacteria. ISME J. 9, 1764-1777. doi: 10.1038/ismej.2014.261

Urakawa, H. (2014). "The family Moritellaceae," in The ProkaryotesGammaproteobacteria, eds E. Rosenberg, E. F. DeLong, S. Lory, E. Stackebrandt, and F. Thompson (Heidelberg: Springer-Verlag), 477-489.

Van Bleijswijk, J. D. L., Whalen, C., Duineveld, G. C. A., Lavaleye, M. S. S., Witte, H. J., and Mienis, F. (2015). Microbial assemblages on a cold-water coral mound at the SE Rockall Bank (NE Atlantic): interactions with hydrography and topography. Biogeosciences 12, 1509-1542. doi: 10.5194/bgd-121509-2015

Vezzulli, L., Pezzati, E., Huete-Stauffer, C., Pruzzo, C., and Cerrano, C. (2013). 16SrDNA pyrosequencing of the Mediterranean gorgonian Paramuricea clavata reveals a link among alterations in bacterial holobiont members, anthropogenic influence and disease outbreaks. PLoS ONE 8:e67745. doi: 10.1371/journal.pone.0067745

Wafar, M., Wafar, S., and David, J. J. (1990). Nitrification in reef corals. Limnol. Oceanogr. 35, 725-730. doi: 10.4319/lo.1990.35.3.0725

Wagner-Dobler, I., and Biebl, H. (2006). Environmental biology of the marine Roseobacter lineage. Ann. Rev. Microbiol. 60, 255-280. doi: 10.1146/annurev.micro.60.080805.142115

Wang, Q., Garrity, G. M., Tiedje, J. M., and Cole, J. R. (2007). Naive Bayesian classifier for rapid assignment of rRNA sequences into the new bacterial taxonomy. Appl. Environ. Microbiol. 73, 5261-5267. doi: 10.1128/AEM. 00062-07

Warnes, G., Bolker, B., Bonebakker, L., Gentleman, R., Liaw, W., Lumley, T., et al. (2015). Gplots: Various R Programming Tools for Plotting Data. Available at: https://cran.r-project.org/web/packages/gplots/index.html

Wegley, L., Edwards, R., Rodriguez-Brito, B., Liu, H., and Rohwer, F. (2007). Metagenomic analysis of the microbial community associated with the coral Porites astreoides. Environ. Microbiol. 9, 2707-2719. doi: 10.1111/j.14622920.2007.01383.x

White, M., Mohn, C., De Stingter, H., and Mottram, G. (2005). “Deep-water coral development as a function of hydrodynamics and surface productivity around the submarine banks of the Rockall Trough," in Cold-Water Corals and Ecosystems, eds N. E. Atlantic and J. M. Roberts (Heidelberg: Springer), 503-514.

Whiteaves, J. F. (1901). Catalogue of the Marine Invertebrata of Eastern Canada, Vol. 722. Calgary, AB: Geological Survey of Canada.

Wiese, J., Thiel, V., Gartner, A., Schmaljohann, R., and Imhoff, J. F. (2009). Kiloniella laminariae gen. nov., sp. nov., an alphaproteobacterium from the marine macroalga Laminaria saccharina. Int. J. Syst. Evol. Microbiol. 59, 350 356. doi: 10.1099/ijs.0.001651-0

Williams, W. M., Viner, A. B., and Broughton, W. J. (1987). Nitrogen-fixation (acetylene-reduction) associated with the living coral Acropora variabilis. Mar. Biol. 94, 531-535. doi: 10.1007/BF00431399

Xu, Y. (2003). Moritella profunda sp. nov. and Moritella abyssi sp. nov., two psychropiezophilic organisms isolated from deep Atlantic 
sediments. Int. J. Syst. Evol. Microbiol. 53, 533-538. doi: 10.1099/ijs.0. 02228-0

Yakimov, M. M., Cappello, S., Crisafi, E., Tursi, A., Savini, A., Corselli, C., et al. (2006). Phylogenetic survey of metabolically active microbial communities associated with the deep-sea coral Lophelia pertusa from the Apulian plateau, Central Mediterranean Sea. Deep Sea Res. Part I Oceanogr. Res. Pap. 53, 62-75. doi: 10.1016/j.dsr.2005.07.005

Yang, C. S., Chen, M. H., Arun, A. B., Chen, C. A., Wang, J. T., and Chen, W. M. (2010). Endozoicomonas montiporae sp. nov., isolated from the encrusting pore coral Montipora aequituberculata. Int. J. Syst. Evol. Microbiol. 60, 1158-1162. doi: 10.1099/ijs.0.014357-0

Yang, Q., Dong, J., Zhang, Y., Ling, J., Wang, D., Wu, M., et al. (2015). Diversity analysis of diazotrophs associated with corals from Xisha and Sanya, South China Sea. Aquat. Ecosyst. Health 18, 433-442. doi: 10.1080/14634988.2015.1092850

Yang, S., Sun, W., Zhang, F., and Li, Z. (2013). Phylogenetically diverse denitrifying and ammonia-oxidizing bacteria in corals Alcyonium gracillimum and Tubastraea coccinea. Mar. Biotechnol. 15, 540-551. doi: 10.1007/s10126013-9503-6
Zehr, J. P., and Kudela, R. M. (2011). Nitrogen cycle of the open ocean: from genes to ecosystems. Ann. Rev. Mar. Sci. 3, 197-225. doi: 10.1146/annurev-marine120709-142819

Zhang, Y., Ling, J., Yang, Q., Wen, C., Yan, Q., Sun, H., et al. (2015). The functional gene composition and metabolic potential of coralassociated microbial communitites. Sci. Rep. 5, 16191. doi: 10.1038/ srep 16191

Conflict of Interest Statement: The authors declare that the research was conducted in the absence of any commercial or financial relationships that could be construed as a potential conflict of interest.

Copyright (c) 2016 Lawler, Kellogg, France, Clostio, Brooke and Ross. This is an open-access article distributed under the terms of the Creative Commons Attribution License (CC BY). The use, distribution or reproduction in other forums is permitted, provided the original author(s) or licensor are credited and that the original publication in this journal is cited, in accordance with accepted academic practice. No use, distribution or reproduction is permitted which does not comply with these terms. 